\title{
Dva mimořádné hroby z laténského pohřebiště v Rousínově
}

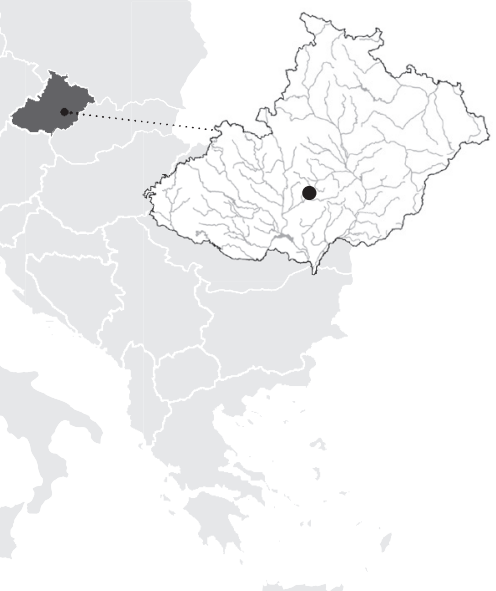

\section{Two exceptional graves from La Tène cemetery in Rousínov}

- Ivan Čižmářr*, Blanka Mikulková, Matěj Kmošek, Michal Chovanec, Jiří Kala-

\section{KEYWORDS:}

La Tène period - cemetery - South Moravia - female chain-belt warrior cremation

\section{ABSTRACT}

Development-led excavation in Rousinov in 2017 uncovered a La Tène cemetery in which 30 graves were excavated. Out of these, two exceptional graves, a rich female inhumation and a warrior's cremation grave, are discussed in detail in this paper. In addition to typological determination of artefacts, the paper includes the results of a survey and conservation work on metal artefacts and anthropological analysis. The inhumation burial of a gracile woman at the age of about 30 years (H823) contained, among other things, a complete bimetallic chain-belt; its furnishing can be dated to LT B2/C1. The warrior's cremation contained, among other things, an undeformed sword in its scabbard and a spear-head with an exceptionally decorated socket; the grave goods date to LT C1.

\section{* Corresponding author - E-mail address: ivancizmar@uapp.cz}

\section{Úvod}

V roce 2017 provedl Ústav archeologické památkové péče Brno, v. v. i. záchranný archeologický výzkum na stavbě skladové plochy a obslužné komunikace v areálu firmy Ferobet v Rousínově (okres Vyškov). Během výzkumu se specifickými okolnostmi (viz níže) bylo mimo jiné z větší části odkryto laténské pohřebiště, jehož kompletní vyhodnocení bude v budoucnu předmětem rozsáhlejší studie.

$\mathrm{Z}$ třiceti prozkoumaných laténských žárových a kostrových hrobů vybočovaly svou výbavou dva, a to žárový pohřeb bojovníka (H821) a skelet bohatě vybavené ženy (H823).

Publikaci celého pohřebiště není s ohledem na množství hrobů $\mathrm{v}$ dohledné době možné provést, výše uvedené celky si však především díky inventáři (řetězový opasek, meč v pochvě, zdobené kopí) zaslouží bez dalšího odkladu podrobnější zhodnocení.

\section{Lokalizace naleziště}

Město Rousínov leží z geomorfologického hlediska ve sníženině Vyškovské brány, která je přirozeným spojovacím prostorem mezi Hornomoravským úvalem na severu a Dyjsko-svrateckým úvalem na jihu. Severně od města vystupují jižní výběžky Drahanské vrchoviny. Přirozenou osu Vyškovské brány zde tvoří potok Rakovec, který protéká 300 m jižně od zkoumané plochy. Plocha záchranného archeologického výzkumu z roku 2017 (obr. 1) se nacházela v intravilánu původní místní části Rousínovec, na mírném, jižně exponovaném svahu, v nadmořské výšce 236 m (Y: 578361.48; X: 1162401.11).

\section{Historie naleziště}

Archeologické stopy na lokalitě byly zjištovány již od 19. století, kdy poblíž vznikla cihelna (cihlářské pece, provozy a těžební prostor ležely $320 \mathrm{~m}$ severozápadně od aktuálně zkoumané plochy). Odtěžování svahu probíhalo od vrcholu západním a jižním směrem. Během těžebních prací zde bylo prozkoumáno neznámé množství archeologických objektů z různých období pravěku a raného středověku (Ličman 1921, 31). Významnou komponentu tvořily laténské kostrové hroby, z nichž A. Procházka zmiňuje jeden mužský bojovnický a dva ženské bohatě vybavené (Procházka 1937, 92-93, nejnověji Čižmářová 2013, 171-173). Tato skupinka hrobů ležela ve vzdálenosti 200 m severozápadně od námi zkoumané plochy. Současné rozsáhlé záchranné výzkumy v místě probíhají od 80. let 20. století (Čižmář, Geisler 1987, 66; Přichystal 2005; Geislerová, Parma 2013, 286; 2018, 301; Mikulková 2018a, 103-107, 301).

Z hlediska zkoumaného období spadá lokalita Rousínov do regionu s mimořádnou koncentrací keltských pohřebišté, odkrývaných již od počátků minulého století, přičemž mnohá naleziště jsou pro poznání moravských laténských pohřebišt 


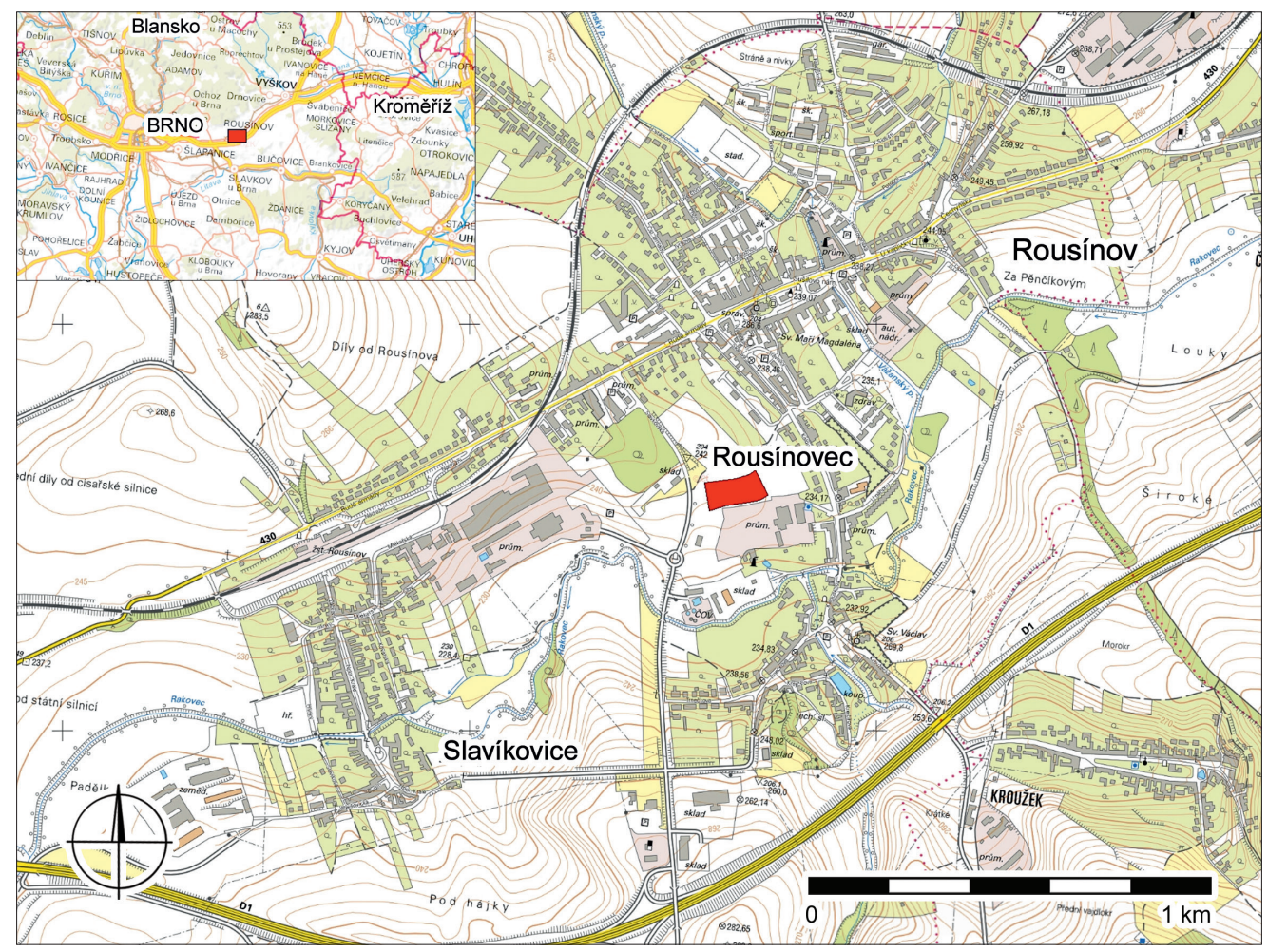

Obr. 1. Lokalizace plochy výzkumu (červeně). Autor M. Kmošek, zdroj: Český úřad zeměměřický a katastrální ZM10.

Fig. 1. Location of excavation area (red). Author M. Kmošek,

source: State Administration of Land Surveying and Cadastre ZM10.

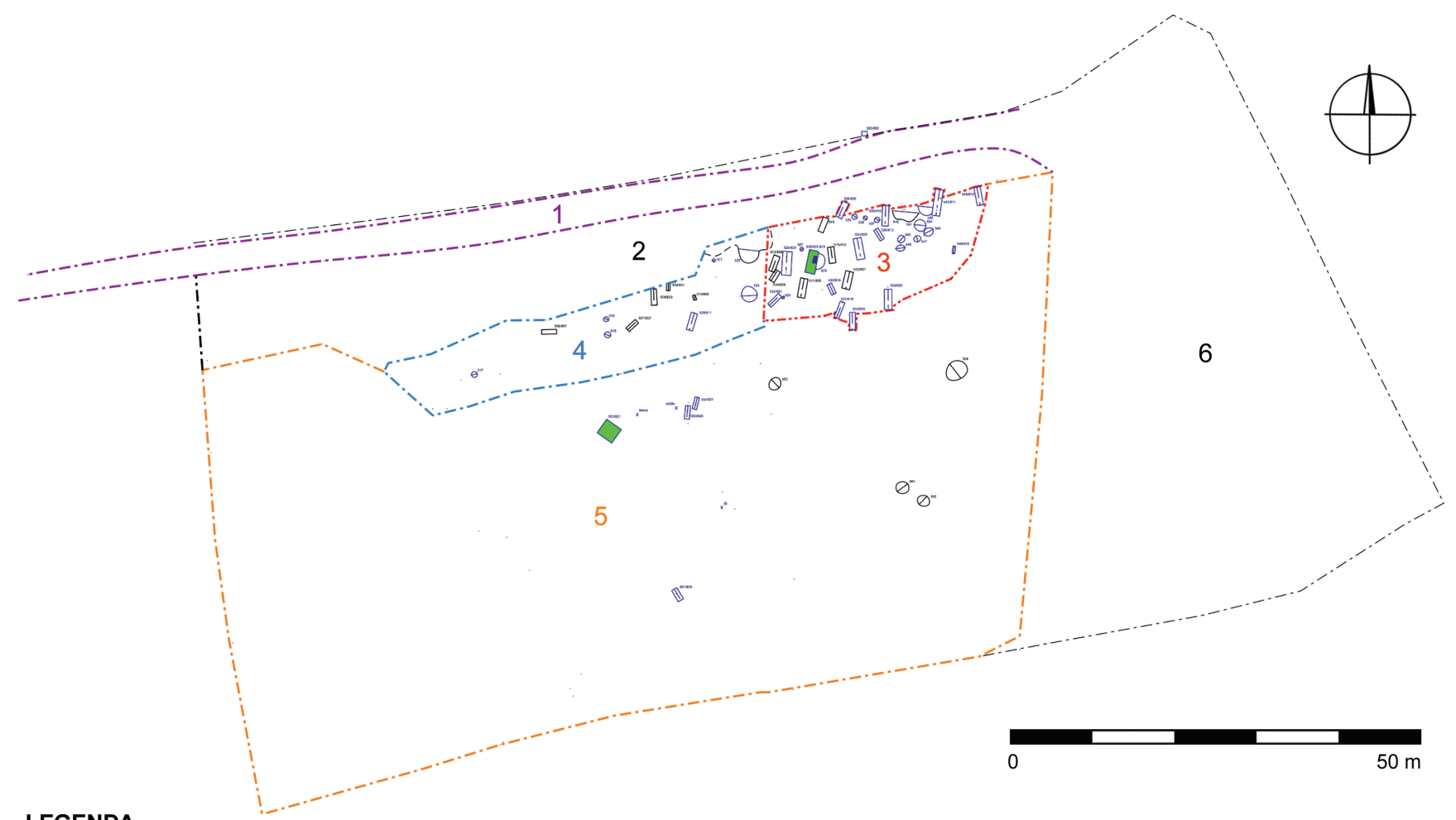

1 - CESTA - doposud nezkoumáno, zaježděno těžkou stavební mechanizací v průběhu září 2017

2 - SKRÝVKA 25. - 26. 4. 2018 - proběhl dohled, zjištěn jeden archeologický objekt - nekopáno

3 - PROZKOUMÁNO

4 - NEDOSKRYTO - prozkoumáno pouze částečně

5 - ČÁSTEČNĚ SKRYTO - plošný výzkum neproběhl

- jednoznačně archeologicky pozitivní, sídliště a pohřebiště

- prozkoumány pouze soliterní objekty

6 - UVOLNĚNO STAVEBNÍKOVI - archeologicky negativní

Obr. 2. Celkový plán výzkumu se zvýrazněním dvou mimořádných hrobů H821 a H823 (zeleně). Autor D. Vitulová.

Fig. 2. Overall excavation plan highlighting the two exceptional graves H821 and H823 (green). Author D. Vitulová. 
klíčová. V těsné blízkosti jsou to nálezy hrobů přímo z místních částí Rousínova, tedy Kroužku, Rousínovce a Slavíkovic, dále významné lokality v Holubicích, Křenovicích, Marefách, Slavkově a jiné (srov. např. Červinka 1902; Procházka 1937; Meduna 1980, Karte 1; Čižmářová 2009; 2013).

\section{Okolnosti výzkumu}

Záchranný archeologický výzkum (ZAV) na stavbě skladové plochy a obslužné komunikace v areálu firmy Ferobet v Rousínově (plán výzkumu viz obr. 2) byl v první fázi realizován formou dohledu během mechanických skrývek, během nichž byly odkryty první laténské hrobové celky. Z tohoto důvodu bylo 24. srpna 2017 přistoupeno k druhé etapě ZAV, vlastnímu terénnímu odkryvu. Nejprve byl prozkoumán silně porušený dětský kostrový hrob z doby laténské v severní části plochy. Následně (1. záŕí) byl na částečně skryté ploše proveden detektorový průzkum, díky němuž se podařilo zachytit první žárové laténské hroby. S ohledem na jejich narušení byla zahájena okamžitá exkavace a současně byla v tomto prostoru ještě týž den se svolením investora provedena částečná skrývka ornice vhodnější strojní mechanizací, která odhalila více než dvě desítky laténských kostrových hrobů (v této skupině byl také bohatý kostrový ženský hrob H823). Archeologické práce probíhaly také následující pracovní den (4. září), investor však téhož dne odmítl provádění dalšího výzkumu, který tak musel být na jeho popud přerušen, a to z důvodu, že stavební záměr ruší a lokalitu chce zakonzervovat. Následovalo zdlouhavé a komplikované jednání mezi zainteresovanými stranami, přičemž nebylo dosaženo shody. ${ }^{1}$ Později se podařilo dosáhnout alespoň kompromisního řešení, kdy majitel umožnil provést průzkum při skrývce zachycených hrobů. ${ }^{2}$ V neúplně skryté ploše byl při souběžně probíhajícím detektorovém průzkumu objeven hrob H821, který byl také exkavován (Mikulková 2018b, 136, 198, 212).

Pokud to komplikované podmínky na výzkumu umožňovaly, byl záchranný výzkum proveden běžným způsobem, tj. sídlištní objekty byly kopány na profil, který byl následně kresebně a fotograficky zdokumentován, a poté došlo k prozkoumání druhé poloviny objektů, jejichž půdorys byl opět zdokumentován (vše v měřítku $1: 20$ ). Hlubší kostrové hroby byly sníženy rýčem a následně preparovány, mělké kostrové hroby a žárové hroby byly preparovány př́ímo. U všech hrobových nálezů byla provedena velmi podrobná fotografická a kresebná dokumentace (měřítko $1: 10$ ) a geodetické zaměření.

Mimořádné nálezy železného meče v hrobu H821 a ženské pásové garnitury v hrobu H823, kterými se mimo jiné detailně zabývá tato studie, byly vyjmuty v bloku i s okolní zeminou, umístěny na pevné desky a pro přepravu ke konzervaci zabaleny do LDPE folie.

Přes neprríznivé podmínky se díky velkému nasazení záchranného týmu nakonec podařilo odkrýt 30 hrobů $z$ doby laténské, z toho 24 kostrových a 6 žárových. Z kostrových hrobů se podařilo určit 9 mužských, 9 ženských a 6 dětských. Podle předběžného zhodnocení byly kostrové hroby jak zcela bez výbavy (4), tak i se standardním (ne př́liš početným) inventářem (14). Vyskytly se ovšem také hroby poměrně bohaté (6). Z posledně jmenovaných se pak vyjímá prezentovaný bohatý ženský pohřeb - hrob H823. Žárové hroby lze z hlediska výbavy rozdělit podobným způsobem, nejvýraznější inventář poskytl prezentovaný žárový bojovnický hrob H821 (obr. 3).

\section{Popis archeologických objektů a artefaktư ${ }^{3}$}

Hrob H821 (objekt 553) - žárový pohřeb

Jak již bylo zmíněno výše, tento hrob byl nalezen při detektorovém průzkumu v části plochy skryté pouze na úroveň podorničí. Na povrchu nebyl nijak patrný. Během preparace se ukázalo,

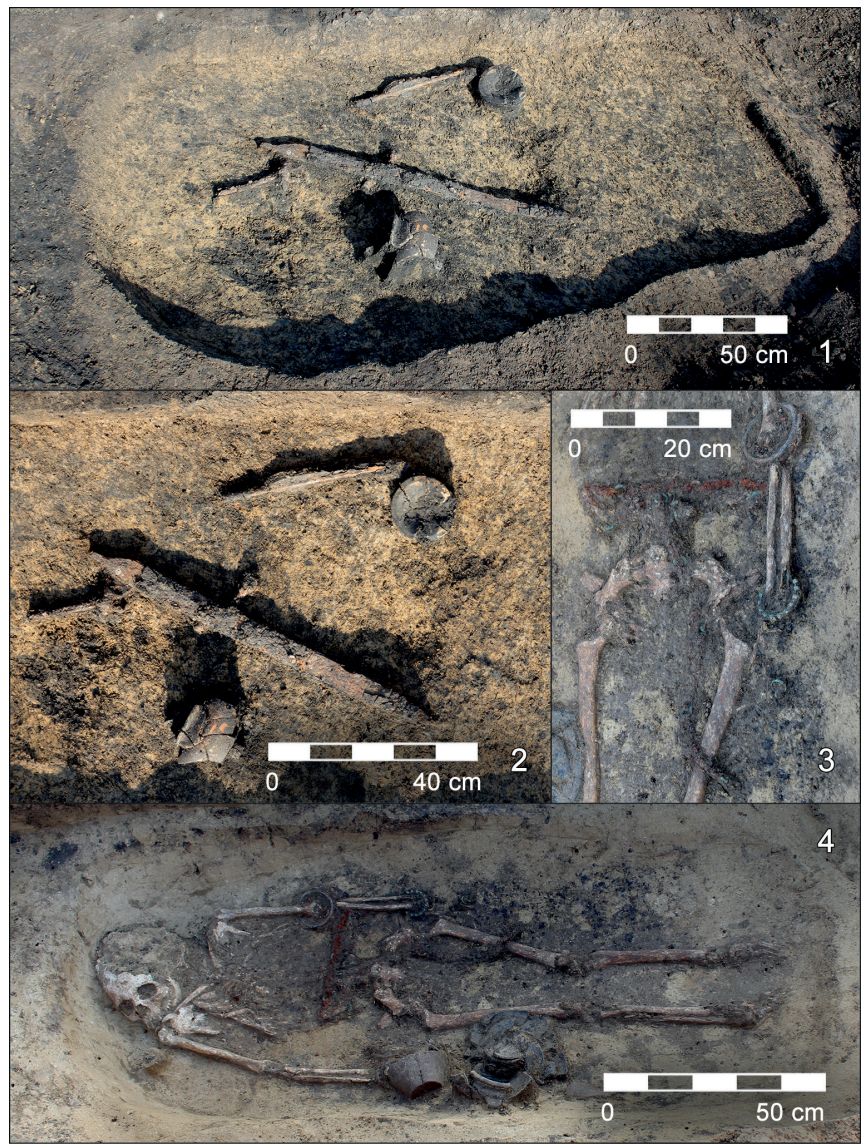

Obr. 3. Terénní fotografická dokumentace hrobů H821 a H823; 1 - hrobová jáma H821; 2 - detail artefaktů v hrobu H821; 3 - detail opaskového řetězu a dalších artefaktů v hrobu H823; 4 - zahloubenina hrobové jámy H823. Foto B. Mikulková.

Fig. 3. Field photographic documentation of graves H821 and H823; 1 - grave pit H821; 2 - detail of artefacts in grave H821; 3 - detail of a chain-belt and other artefacts in the grave H823; 4 - H823 grave pit depression. Photo by B. Mikulková.

že jde o žárový velmi mělce zahloubený hrob, který se navíc nacházel jen $5 \mathrm{~cm}$ pod povrchem. Hrobová jáma byla orientována ve směru Z-V a měla obdélný tvar se zaoblenými rohy o rozměrech $187 \times 98 \times 7$ cm a mělký mísovitý profil (obr. 3: 1; obr. 4). V centrální části hrobu ležel diagonálně železný meč (2) v silně poškozené pochvě (3), pod ním byla část opaskového řetězu (4a, 4b) a fragment železného náramku (5). U severního okraje hrobové jámy byl nalezen železný list kopí (1) a zlomky druhotně přepálených nádob (7-11). Další zlomky (6) přepálené nádoby (zdobené kolkováním) ležely poblíž meče (obr. 3:2). Zbytky kremace byly volně rozptýlené po ploše hrobové jámy, větší koncentrace spálených fragmentů se nacházela pod shlukem keramiky (6).

1. Železný list kopí. List značně olámaný, hrot odlomen, nevýrazné středové žebro. Relativně dlouhá tulej na povrchu opatřena rytou výzdobou esovitými motivy a motivy rybích měchýřo̊ umístěných v kruzích. R.: celková d. $355 \mathrm{~mm}$, d. tuleje $95 \mathrm{~mm}$, $\varnothing$ tuleje $18 \mathrm{~mm}$. Inv. č. A 120026. Obr. 4: 1.

2. Železný meč s nevýrazným středovým žebrem a odlomeným trnem jílce (dochoval se v samostatném fragmentu), k jílci náleží i dva spojené nýty s malou půlkulatou hlavicí. R.: celková dochovaná d. $815 \mathrm{~mm}$, š. $47 \mathrm{~mm}$, dochovaná d. jílce $60 \mathrm{~mm}, \varnothing$ hlavic nýtů 9-10 mm, d. spojených nýtů $29 \mathrm{~mm}$. Inv. č. A 120025. Obr. 4: 2.

3. Fragmenty přední části železné plechové pochvy (přes $30 \mathrm{ks}$ ) včetně fragmentu zadní horní části se závěsným poutkem s kruhovými postranními destičkami, poblíž dochován drobný nýtek. Dále se dochovaly dva korýtkovité okrajové 
fragmenty nákončí pochvy. R.: d. poutka $40 \mathrm{~mm}, \varnothing$ postranních destiček $18 \mathrm{~mm}, \varnothing$ hlavice nýtu $7 \mathrm{~mm}$, d. fragmentů nákončí 43 a 40 mm. Inv. č. A 120027. Obr. 4: 3.

4. Fragmenty železného opaskového řetězu (5 ks) z krátkých oválných zploštělých kroucených článků, dva fragmenty jsou zakončeny větším kruhovým okem, před nímž se nachází o něco větší oválný článek. K řetězu náležejí další amorfní Fe úlomky (celkem 5 ks). R.: d. 100, 90, 52, 42 a 41 mm, Ø oválných článků 25-30 × $10 \mathrm{~mm}, \varnothing$ většího oválného článku $35 \times 15$ mm. Inv. č. A 120024. Obr. 4: 4a, 4b.

5. Fragment železného náramku. R.: d. $49 \mathrm{~mm}, \varnothing$ cca $80 \mathrm{~mm}$, $\varnothing$ tyčinky 6 mm. Inv. č. A 120027A. Obr. 4: 5.

6. Fragmenty z horní části keramické nádoby, snad vázovitého tvaru, druhotně přepálené (2 větší profily nádoby zdobené kolky, 4 zlomky okrajů, 1 zlomek výdutě s kolky, 22 zlomků výdutě). Ovalený okraj, pod nízkým hrdlem plastické obvodové žebro, pod ním po obvodu výzdoba rytých kroužků - na dochované části nádoby zjištěny tři skupinky po třech kroužcích. Povrch šedý, hlazený, materiál jemný, tvrdě pálený, kruh. R.: Ø okraje 165 mm, Ø kroužků 7 mm. Inv. č. A 120016. Obr. 5: 6.

7. Fragmenty z horní části keramické nádoby, druhotně přepálené (1 větší okraj, 2 menší zlomky okrajů, 25 zlomků výdutě). Původně šedý hlazený povrch z větší části do oranžova přepálený, materiál jemný, tvrdě pálený, kruh. R.: $\varnothing$ okraje 300 mm. Inv. č. A 120017. Obr. 5: 7.

8. Fragmenty z výdutě keramické nádoby $(28 \mathrm{ks})$, druhotně přepálené. Původně šedý hlazený povrch z větší části do oranžova přepálený. Inv. č. A 120018. Obr. 5: 8.

9. Fragmenty ze dna keramické nádoby, druhotně přepálené (4 ks). Původně šedý hlazený povrch z větší části do oranžova přepálený, materiál jemný, tvrdě pálený, kruh. R.: Ø dna 130 mm. Inv. č. A 120019. Obr. 5: 9.

10. Fragment podhrdlí keramické nádoby. Povrch světle okrový, materiál jemný, tvrdě pálený, kruh? Inv. č. A 120020. Obr. 5: 10 .

11. Fragment ze dna keramické nádoby, druhotně přepálené. Původně šedý hlazený povrch z větší části do oranžova přepálený, materiál jemný, tvrdě pálený, kruh. R.: $\varnothing$ dna 130 mm. Inv. č. A 120021. Obr. 5: 11.

12. Fragment keramické nádoby - intruze (neolit). Inv. č. A 120022.

\section{Hrob H823 (objekt 528) - kostrový pohřeb}

Hrob se nacházel v části plochy, která byla skryta až na úroveň podloží. Hrobová jáma, která porušovala sídlištní objekt, byla orientována ve směru S-J a měla obdélný tvar se zaoblenými rohy o rozměrech $270 \times 120 \times 45 \mathrm{~cm}$. Na dně byla menší obdélníková zahloubenina $(158 \times 71 \times 17 \mathrm{~cm})$, která vznikla patrně použitím dřevěného obložení či rakve. V této zahloubenině se nacházela kostra uložená v natažené poloze na zádech s lebkou k severu, obličejem stočeným vpravo a pažemi podél těla (obr. 3: 3; obr. 6). Na ramenou ležely dvě identické bronzové spony ( 1 - pravé rameno, 2 - levé rameno), další železná spona ležela na pravé straně hrudníku (3). V loketní oblasti levé paže byl navlečen sapropelitový (4) a železný (5) nápažník. Na téže ruce byl v oblasti zápěstí bronzový náramek (8). Na prstech levé ruky byly umístěny dva prsteny, bronzový (9) a železný (14). U pravého zápěstí se nacházely zlomky železného náramku (7). Mezi pravou stehenní kostí a stěnou hrobové jámy ležely dvě nádoby $(10,11)$ a fragment další nádoby (13). V oblasti pasu byla zjištěna kompletní bimetalická pásová garnitura (6). Horizontální část garnitury byla umístěna po obvodu břicha nad úrovní pasu a její svislá část směřovala přes levou pánevní kost na levou stehenní kost (obr. 3: 3). Hrobová jáma porušovala pravěký sídlištní objekt. Při snižování hrobu byl v horní části zásypu nalezen také silně torzovitě zachovaný pohřeb novorozence bez milodarů (H822).

1. Bronzová spona s velkou kuličkou na patce. Krátký oble klenutý lučík, patka připojena zdobenou svorkou, zachycovač a kulička zdobeny diagonálními rýhami. Vinutí 2 + 2 závity, vnitřní tětiva. Jehla chybí. R.: d. 34 mm. Inv. č. A 119896. Obr. 6: 1.

2. Bronzová spona s velkou kuličkou na patce, identická s předchozí. Krátký oble klenutý lučík, patka připojena zdobenou svorkou, zachycovač a kulička zdobeny diagonálními rýhami (obr. 8: 1, 2). Vinutí $2+2$ závity, vnitřní tětiva, jehla deformovaná. R.: d. 33 mm. Inv. č. A 119897. Obr. 6: 2.

3. Část železné drátěné spony. Klenutý lučík, vinutí $2+2$ závity s vnější spodní tětivou, patka a jehla chybí. R.: d. $74 \mathrm{~mm}$. Inv. č. A 119900. Obr. 6: 3.

4. Sapropelitový nápažník - lehce deformovaný kruh, materiál kruhového průřezu. Na povrchu stopy korozních produktů železa od přilehlého železného nápažníku (obr. 8: 5). Na vnitřní straně zjištěny mikroskopem drobné rovnoběžné diagonální rýhy (obr. 8: 6). R.: Ø vnější $88 \mathrm{~mm}$, Ø vnitřní $75 \mathrm{~mm}$, Ø materiálu 6,5 mm, délka rýh 2 mm. Inv. č. A 119904. Obr. 6: 4.

5. Fragmenty železného nápažníku, dle rozličného průměru materiálu původně snad vícekrát stočeného. R.: $\varnothing$ neměřitelný, odvozený ${ }^{4}$ vnitřní $\varnothing 75 \mathrm{~mm}, \varnothing$ materiálu 2 a 3,5-4 mm. Inv. č. A 119901. Obr. 6: 5.

6. Fragmenty bimetalického opaskového řetězu, složeného $\mathrm{z}$ větších bronzových kroužků spojených dvěma řetízky z menších železných oček. Železná očka jsou zhotovena $\mathrm{z}$ drátu polokruhového průřezu. $\mathrm{V}$ místě napojení na bronzový kroužek jsou železná očka vždy oválná, ostatní jsou výhradně kruhová. Na povrchu železných fragmentů lokálně zachovány textilní pozůstatky (obr. 12: 3, 4). Součástí opasku je kuželkovitý závěsek a bronzová pasová zoomorfní zápona s háčkem ve tvaru zvířecí hlavičky na jedné a s kroužkem na druhé straně a se středovou částí ve tvaru kř́íze. Zápona byla zaklesnuta do pátého bronzového kroužku. Rekonstruovatelný obvod pasu je tak přibližně $60 \mathrm{~cm}$, délka volně visící části přibližně $45 \mathrm{~cm}$. R.: celková rekonstruovaná d. opasku cca $1050 \mathrm{~mm}$, $\varnothing$ bronzových kroužků $20 \mathrm{~mm}$, d. spojovacích řetízků 95-105 mm, Ø kroužků spojovacích řetízků 7-8 mm, $\varnothing$ oválných oček spojovacích řetízků 12-14 × 8 mm, d. zápony 45 mm, d. kuželkovitého závěsku 18 mm. Inv. č. A 120023. Obr. 6: 6.

7. Fragmenty železného drátěného spirálového náramku (11 ks + 6 ks) získaných při plavení výplně nádoby č. 10; vzhledem $\mathrm{k}$ tomu, že náramek ležel v těsné blízkosti nádoby, je pravděpodobné, že se tyto zlomky do její výplně dostaly působením postdepozičních procesů. Náramek byl dle dochovaných fragmentů spojených korozí spirálovitě stočen minimálně ze čtyř paralelních drátů různého průměru. R.: $\varnothing 50-55 \mathrm{~mm}$, $\varnothing$ materiálu 2-3,5 mm. Inv. č. A 119902. Obr. 6: 7.

8. Bronzový náramek - neuzavřený kruh z tenké tyčinky, na níž jsou po obvodu navlečeny odlévané kvádř́íky, jež jsou opatřeny soustřednými kroužky shora i po stranách. Mezi jednotlivými kvádř́iky jsou na tyčince vytepaná nevýrazná příčná žebra (obr. 8: 3). Oba konce předmětu spojeny tak, že v koncovém kvádř́iku je zásek, do něhož je zasunut zploštělý druhý konec náramku, oba konce jsou opatřeny př́ićnými otvory a původně zajištěny čepem, jenž se nedochoval (obr. 8: 4). R.: $\varnothing$ vnější (s kvádříky) $64 \times 59 \mathrm{~mm}, \varnothing$ vnitřní $52 \times 47 \mathrm{~mm}, \varnothing$ kvádř́íků 6 mm. Inv. č. A 119898. Obr. 6: 8.

9. Bronzový prsten, jedna polovina těla zdobena zaškrcováním. R.: Ø 19 mm, max. š. 4,5 mm. Inv. č. A 119899. Obr. 6: 9. 


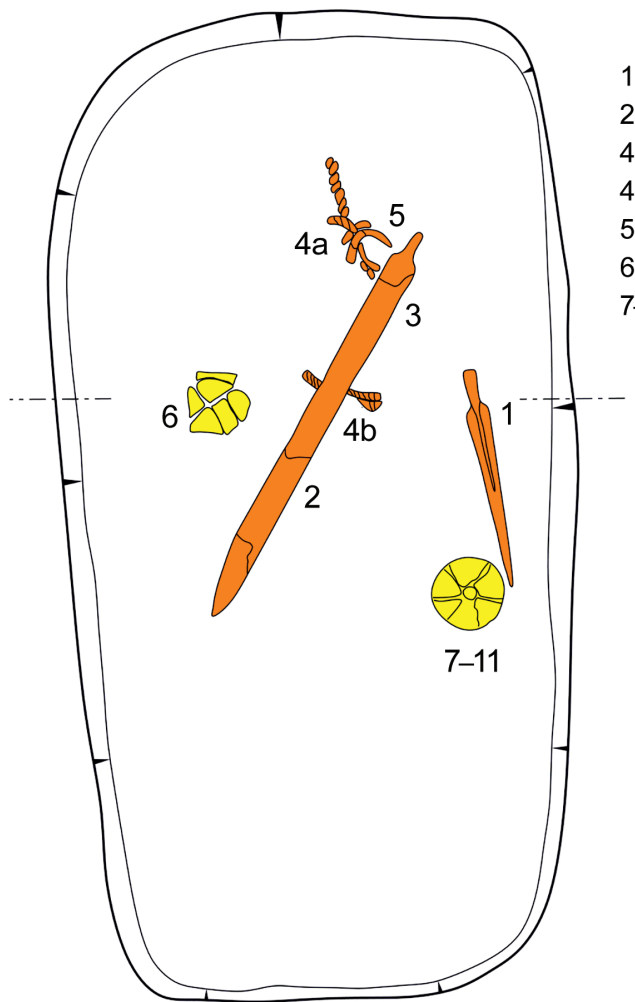

Obj. 553 H821
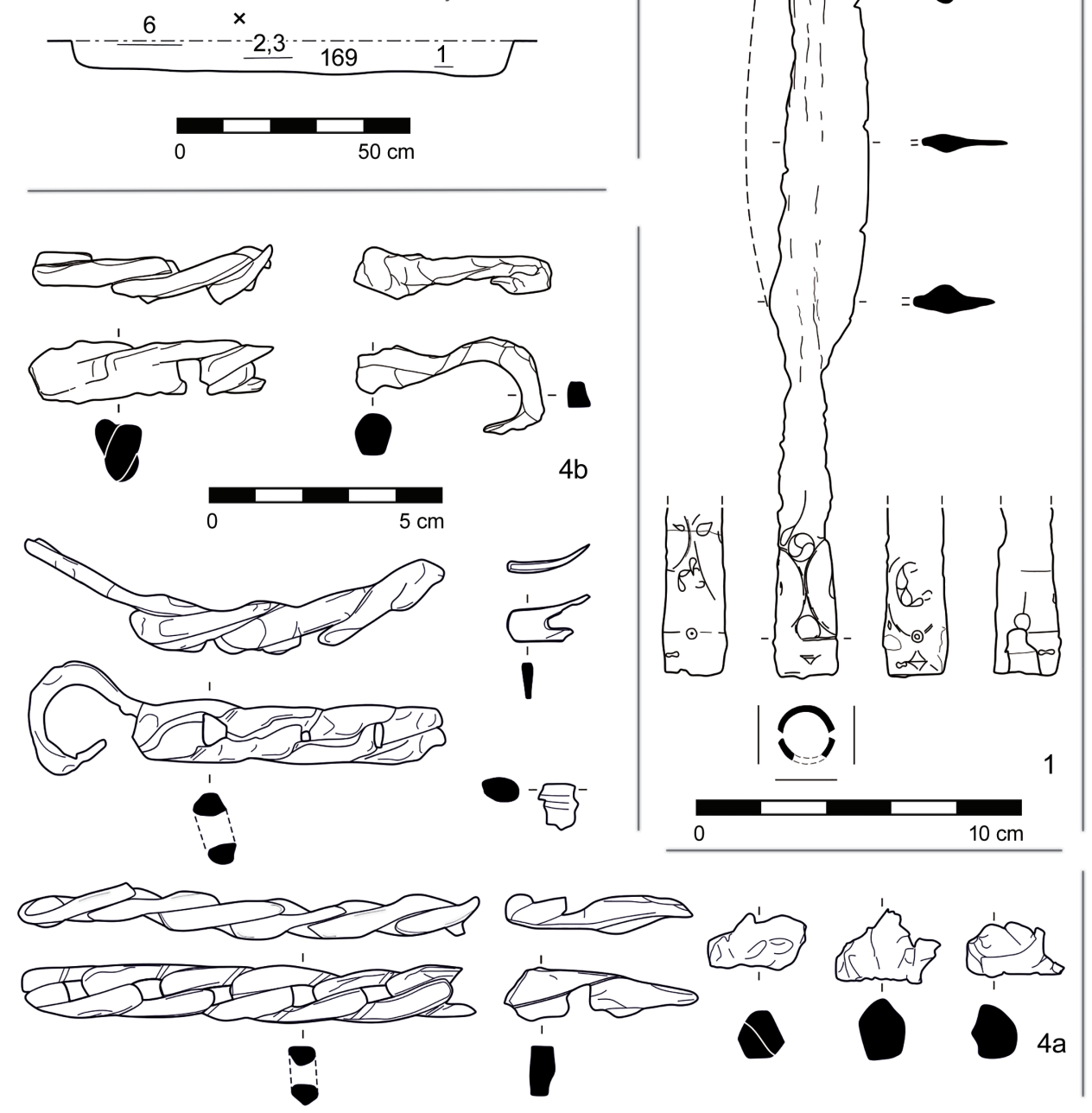

1 - kopí

2, 3 - meč v pochvě

$4 a-$ opaskový řetěz 1 . část

$4 \mathrm{~b}$ - opaskový řetěz 2. část

5 - náramek

6 - keramické fragmenty

7-11 - keramické fragmenty

$\square$ Železo

$\square$ Keramika

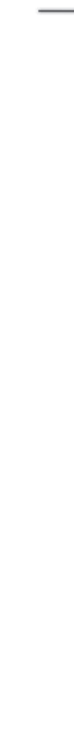


10. Malá bikónická keramická nádoba se silným ovaleným okrajem, v horní části výdutě obvodová plastická lišta, na povrchu úprava v podobě svazků svislých rýh. Povrch drsný, cihlově zbarvený, materiál hrubý s příměsí písku, tvrdě pálený, kruh. R.: v. 105 mm, $\varnothing$ okraje $95 \mathrm{~mm}, \varnothing$ dna $62 \mathrm{~mm}$. Inv. č. A 119891. Obr. 7: 10.

11. Vysoká keramická nádoba - váza na nožce. Ovalený okraj, nízké hrdlo naznačeno prohnutím, pod ním silné obvodové plastické žebro, další žebro v nejužším místě mezi výdutí a profilovanou dutou nožkou. Povrch šedočerný, hlazený, materiál jemná hlína tvrdě pálená, kruh. R.: v. 208 mm, Ø okraje 132 mm, Ø nožky 115 mm. Inv. č. A 119892. Obr. 7: 11.

12. Keramika - sloučeno s č. 11.

13. Fragment keramické nádoby - intruze (neolit). Inv. č. A 119893.

14. Fragment železného, patrně spirálového prstenu z tenkého drátu - dva paralelní dráty shodného průměru spojené korozí. R.: d. fragmentu $14 \mathrm{~mm}$, š. prstenu $3,5 \mathrm{~mm}$, $\varnothing$ drátu 1,5 mm. Inv. č. A 119903. Obr. 6: 14.

\section{Vyhodnocení nálezových celků}

Mezi žárovými hroby z prozkoumané části pohřebiště vyniká hrob H821 s pohřbem s bojovnickou garniturou. Výbavu tvoří kopí a železný meč v plechové železné pochvě zavěšený na řetězovém opasku. Soubor doplňují části keramických nádob. Součásti kroje zemřelého jsou doloženy pouze fragmentem železného náramku, jindy běžné spony chybí. Zbraně nejsou deformované.

Nedeformovaný meč (obr. 4: 2) má celkovou délku 815 mm (přičemž trn jílce je částečně odlomen). Taková délka je příznačná pro mladší tvary těchto zbraní, které dosahují délky až kolem 1000 mm (Pleiner 1993, 165; např. Brno-Chrlice, hrob 9 Čižmářová 2011, tab. 8: 3; Kobylnice, hrob 9 - Čižmářová 2011, tab. 32: 1; Ponětovice, hroby 14, 26 - Čižmářová 2011, tab. 40: 4, 45: 1; Tážaly - Čižmářová 2017, tab. 54: 3) na rozdíl od mečů staršího období (Brunaux, Lambot 1987, 120-121), jejichž délka se pohybuje kolem 650-750 mm. Mladé datování meče naznačují i dva fragmenty hrotitého nákončí pochvy, jaké se vyskytují v hrobech LT C1 (opět Ponětovice, hroby 14, 26; Drnovice - Čižmářová 2013, tab. 15: 12). Tomuto datování odpovídá i dochované závěsné poutko pochvy (obr. 4: 3) s oválnými destičkami běžně dokumentovanými na pochvách mečů ze stupně LT C1.

Meč byl zavěšen na řetězovém, tzv. pancéřovém opasku, $\mathrm{z}$ něhož se dochovalo pouze několik fragmentů (obr. 4: 4a, 4b). Lze předpokládat, že větší část opasku byla kožená. Řetěz je sestaven z krátkých oválných kroucených článků naplocho skovaných a na lícní straně opatřených drobnými vybíjenými důlky, na dvou fragmentech je poslední článek zakončen velkým kruhovým okem. V materiálu z moravských pohřebišt jsou opasky tohoto provedení zastoupeny (napřr. Brno-Chrlice, hrob 9 - Čižmářová 2011, tab. 8: 1; Brno-Maloměřice, rozrušené hroby 15 - Čižmářová 2005, obr. 83: 9; Kobylnice, hrob 9 - Čižmářová 2011, tab. 31: 9-11; Ponětovice, hrob 14 - Čižmářová 2011, tab. 40: 2), a to v celcích datovaných do stupně LT C1.

Nejvýraznější součástí souboru je železný list kopí (obr. 4: 1). Tvar vavř́nového listu i velikost se nevymykají spektru nálezů z moravských pohřebišt', tento exemplář je však zcela výjimečný prítomností výzdoby, jíž je opatřena tulej listu. Rytý dekor pokrývá povrch především spodní části tuleje (na list však již nezasahuje) a je tvořen esovitými motivy a motivy rybích měchýřů, které jsou komponovány do kruhů (obr. 11: 4). Analogický nález v materiálu z moravských pohřebišt není znám, z širšího prostoru střední Evropy však lze uvést několik exemplářů s výzdobou na tuleji, přičemž všechny pocházejí z výbavy žárových hrobů datovaných do stupně LT C1 (žárový hrob z Dalj ve Slavonii, žárový hrob 6 z Dobovy ve Slovinsku, žárový hrob 9 z Iwanowic v Polsku, žárový hrob 1 z Neukirchenu v Dolních Rakousích - Guštin 1984, 353; Szabó, Petres 1992, 111, Pl. 113; Rosen-Przeworska 1963, Pl. 51; Pittioni 1930, 48, Abb. 10; souhrnně Filip 1956, 121, 133, 135, obr. 38: 12, 41: 5, 42:9). Stejně datovaný, a také nejvíce identický, je ovšem nález pocházející z žárového hrobu na slovinské nekropoli Novo mesto - Kandija. Výzdoba na tuleji je podobná motivu vyobrazenému na kopí z rousínovského pohřebiště, také výbava obou hrobů (př́tomnost meče, zdobeného kopí a fragmentu náramku) si je navzájem velmi podobná (Megaw, J., Megaw, M. 2009, 164, Fig. 2, 3). Zdobená kopí se objevují v oblasti od řeky Marny až po Slovinsko a lze předpokládat, že jejich zastoupení původně bylo podstatně vyšší; výzdoba se patrně dochovala pouze na některých exempláŕích. Obecně se však má za to, že především atypické tvary, které svým charakterem vylučují efektivní využití v boji, byly určeny spíše $\mathrm{k}$ obřadním př́ležitostem, př́ípadně jako standarty (Ramsl 2006, 198; Megaw, J., Megaw, M. 2009, 166).

Rytá výzdoba na zbraních z mladých laténských hrobů není na Moravě neznámá, i když je velmi řídká. Její výskyt je však zaznamenán téměř výlučně na pochvách mečů (Charváty - Čižmářová 2017, tab. 49: 1; Kobylnice, hrob 9 - Čižmář 1991, Abb. 2: 2; Ponětovice, hrob 14 - Čižmářová 2011, tab. 40: 10; Postoupky - Čižmářová 2017, obr. 18; Horák 2012, 260-261), ojediněle pak také na štítové puklici (Holubice, hrob 55 - Čižmářová 2009, tab. 22: 1). Je ovšem nutno brát v úvahu i to, že relativně jemná rytá výzdoba povrchu železného předmětu mohla být korozními procesy zcela degradována, nebo její stopy při konzervaci nebyly rozpoznány a eventuálně byly posléze i zničeny. Pro úplnost je třeba zmínit také další typ výzdobných prvků na zbraních, který tvoří bronzové zdobené hlavice nýtů, upevňujících list kopí na ratišti (Brno-Maloměřice, hrob 67; Holubice, hrob 30; Mistřín, hrob 34; Olomouc-Nemilany - souhrnně Čižmář 1991).

Nezdobený fragment železného náramku (obr. 4:5) představuje $\mathrm{v}$ hrobech běžnou součást inventáře zemřelého. S ohledem na skutečnost, že se nedochovalo zakončení ani výzdoba, je těžké jej blíže klasifikovat, prŕípadně chronologicky zařadit.

Celek je doplněn částí keramické nádoby (obr. 5: 6), zřejmě vázovitého tvaru (spodní část se nedochovala). Dochovaná část má běžnou profilaci s lehce ovaleným okrajem, nízkým hrdlem a obvodovým plastickým žebrem na rozhraní hrdla a výdutě, výjimečná je však výzdoba v podobě skupin tří kolkovaných kroužků. Rytá, resp. kolkovaná výzdoba na nádobách z moravských laténských pohřebišt nebo současných sídlišt je obecně velmi ojedinělá, tř̌ebaže její výskyt je zaznamenán (Holubice, hrob 47 - Čižmářová 2009, tab. 19: 15; Velké Hostěrádky, obj. 2 a 3 - Čižmář 1984, obr. 5: 10, obr. 6: 4; dále Bulhary, Hradčovice, Mikulov, Stř̌elice - souhrnně Meduna 1980, 102); nejbližší, ovšem stále málo podobnou, analogii lze spatřovat na nádobě z hrobu 13 z Ponětovic (Čižmářová 2011, 136, tab. 39: 14). Tato výzdoba v podobě seskupení kolků uspořádaných do jednoduchých izolovaných skupin symetricky rozmístěných na povrchu nádoby představuje nesporně relativně mladý druh kolkované výzdoby, jehož počátek lze zařadit již do stupně LT B2. Nálezy podobně datovaných situl známe z celé řady hrobových celků ze slovenského území (např. Bajč-Vlkanovo, hrob 8 - Benadik 1960, tab. IV: 20; Hurbanovo-Abadomb - Benadik 1957, tab. XVI: 14; Malé Kosihy, hroby 133, 507 - Bujna 1995, Taf. 14: B1, 55: A7; Maňa, hroby 124, 137, 144 - Benadik 1983, Taf. XLVI: 7,8, LV: 10, LVIII: 2). Je zřejmé, že kolkovaná výzdoba na mladších nádobách je typická pro oblast Karpatské kotliny, ale na Moravě je cizím prvkem.

Další fragmenty keramických nádob nelze blíže chronologicky zařadit. Nacházejí se mezi nimi zlomky okrajů další snad vázovité nádoby (obr. 5: 7), jakož i zlomky ode dna (obr. 5: 9) a řada střepů $\mathrm{z}$ výdutě a podhrdlí pravděpodobně z obdobných keramických tvarů (obr. 5: 8, 10, 11). 


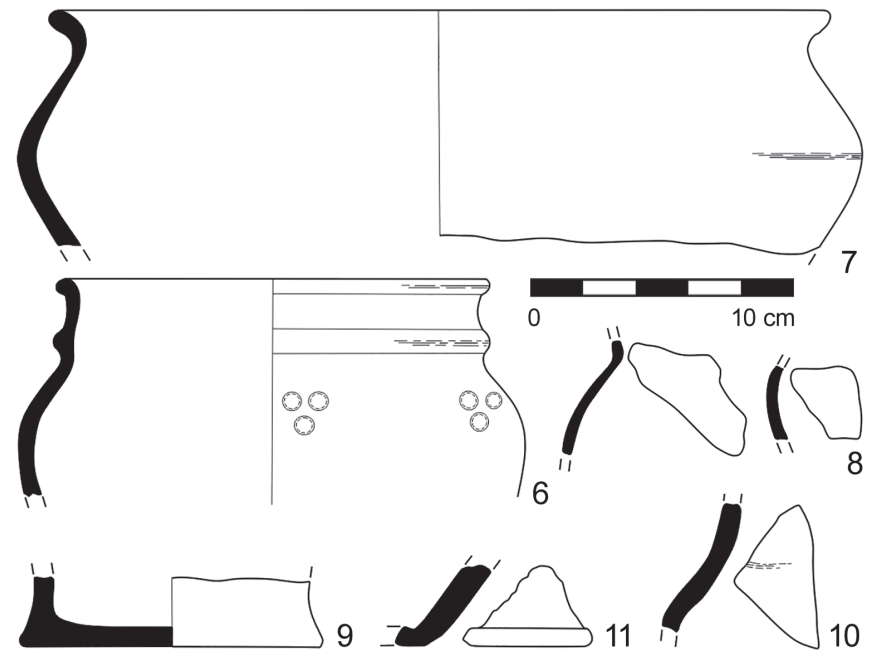

Obr. 5. Kresebná dokumentace keramických nálezů z hrobu H821. Kresba M. Michalíková.

Fig. 5. Drawing of ceramic finds from grave H821. Drawing by M. Michalíková.

Z výčtu keramických zlomků je možné vydedukovat, že se zemřelým na onen svět putovaly nejméně dvě různé vázovité nádoby, jedna opatřená kolky, další bez výzdoby. Vyloučen ovšem není ani vyšší počet nádob.

Nejvýraznějším předmětem, podle kterého lze tento hrobový celek datovat, je tedy list kopí s rytou výzdobou na tuleji. Podobné nálezy jsou datovány do laténského stupně LT C1; toto datování podporuje i výzdoba na keramické nádobě z hrobu, stejně jako celkový charakter nalezeného meče (větší délka, absence středového žebra, tvar čepele) a v neposlední řadě také žárový ritus, který je pro nejmladší laténské hroby na Moravě typický.

Kostrový ženský hrob H823 náleží k výjimečným celkům především vzhledem $\mathrm{k}$ přítomnosti opaskového řetězu. Celou garnituru kromě této luxusní součásti oděvu tvoří dvě párové bronzové spony na ramenou, jedna velká železná spona na prsou, na levé horní končetině železný a sapropelitový nápažník, bronzový náramek a bronzový a železný prsten, na pravé pak železný náramek. Soubor doplňují keramické nádoby, z nichž dvě se dochovaly vcelku a ze třetí zbylo jen několik fragmentů. Nánožníky součástí této nadstandardní hrobové výbavy nebyly. Mimořádnost tohoto hrobu umocňuje také torzo pohřbu novorozence (H822), který byl zjištěn v hrobovém zásypu. S pohřby dětí na moravských laténských pohřebištích se přirozeně setkáváme, avšak nepř́liliš často (např. Čižmářová 2013, 66-68, 89, 91, tab. 4: 5, 8: 4, 9: 1, 11: 1; Čižmářová 2017, 52, 59, tab. 75:2, 80:4), podstatně méně jsou ovšem známy jejich pohřby v hrobu s předpokládaným rodinným př́slušníkem, které se svým charakterem od sebe navzájem odlišují. Z lokality Brno-Černovice popisuje J. Jelínek dvojhrob dospělého jedince a dítěte, v Brně-Horních Heršpicích byly zase spálené pozůstatky dítěte nalezeny v jamce pod kostrovým pohřbem dospělého (Čižmářová 2011, 21). Spolu s dospělým jedincem (snad ženou) bylo pochováno další dítě ve Šlapanicích (Čižmářová 2011, 53). V Kuřrimi byl nalezen hrob ženy, dítě bylo pochováno $\mathrm{v}$ přidružené hrobové jámě (Čižmářová 2011, 50, tab. 16: 2). Na základě zjištěné situace u hrobu z Rousínova není ovšem možné bezpečně rozhodnout, zda byli oba jedinci do hrobu uloženi současně, nebo zda byla menší jáma vykopána později a dítě do ní bylo uloženo dodatečně. Ve všech výše uvedených př́ípadech je však evidentní nebo nanejvýš pravděpodobné, že oba jedinci (dospělý i dítě) byli do hrobu uloženi současně.

Nejvýraznější součástí garnitury je opaskový řetěz sestavený z větších bronzových kroužků spojených dvojicemi řetízků z drobných železných oček (obr. 6: 6); opasek je na jedné straně zakončen zoomorfní záponou, na druhé kuželkovitým závěskem. Na moravských pohřebištích k němu lze uvést řadu analogií (Brno-Maloměřice, hroby 17 a 52 - Čižmářová 2005, obr. 64: 5, 75: 5, 6; Holubice, hrob 21 - Čižmářová 2009, tab. 10: 1, 2; Lovčičky, hrob 2 - Čižmářová 2013, tab. 27: 1, 2, 8; Šlapanice, hrob 6/1999 - Čižmářová 2011, tab. 54: 5, 6, 10). Podobně jako u rousínovského hrobu H823 tyto garnitury neobsahují nánožníky, vyjma celku z Lovčiček. Z typologického hlediska opasek náleží k variantě E2F-Ab podle J. Bujny, charakteristické pro období LT B2/C1 - LT C1 (Bujna 2011, 89-91, tab. 57, obr. 37; k rozšíření srov. též Teleagă 2008, 110-111, Abb. 11-12), zápona pak k jeho typu Gs-K1-b, který datuje do stupně LT Cla (Bujna 2011, 126). Z opaskového řetězu byly materiálově analyzovány dva bronzové spojovací kroužky, zoomorfní zápona a kuželkovitý závěsek (obr. 10; tab. 1). U všech částí se projevilo velmi nehomogenní složení jak z hlediska makroprvků (měd', olovo, cín), tak stopových prvků (zvláště antimon, bismut a zinek). Nejmarkantnější je však rozptyl obsahu železa (0,12-5,13\%). Zvláště u zápony a jednoho z kroužků je jeho zastoupení neobvykle vysoké. To zřejmě poukazuje na nedokonalou rafinaci použitého materiálu, ze kterého nebyla tato nežádoucí nečistota dostatečně odstraněna. Vysoká nehomogenita složení bronzových částí opasku může poukazovat na výrobu z odlišného výchozího materiálu. Tento jev by mohl být způsoben masovou výrobou jednotlivých komponent, jež byly následně libovolně kompletovány do finálních opasků.

\begin{tabular}{|c|c|c|c|c|c|c|c|c|c|c|c|c|c|c|}
\hline Č. vzorku & Inv. č. & Předmět & Část předmětu & $\mathrm{Cu}$ & $\mathbf{P b}$ & Sn & Sb & $\mathrm{Ni}$ & $\mathrm{Fe}$ & $\mathbf{B i}$ & $\mathrm{Zn}$ & Co & As & Ag \\
\hline 1 & A 119898 & náramek & kvádř́ík & 63,76 & 32,68 & 3,20 & 0,07 & 0,03 & 0,00 & 0,28 & 0,05 & 0,00 & 0,00 & 0,00 \\
\hline 2 & A 119898 & náramek & kvádřrík & 69,29 & 26,61 & 3,66 & 0,09 & 0,03 & 0,02 & 0,19 & 0,02 & 0,01 & 0,00 & 0,01 \\
\hline 3 & A 119898 & náramek & kvádřŕk & 65,02 & 31,31 & 3,27 & 0,06 & 0,02 & 0,00 & 0,28 & 0,09 & 0,00 & 0,00 & 0,00 \\
\hline 4 & A 119898 & náramek & tyčinka & 91,87 & 2,14 & 4,87 & 0,07 & 0,04 & 0,53 & 0,02 & 0,00 & 0,02 & 0,42 & 0,00 \\
\hline 5 & A 119897 & spona & kulička & 88,86 & 8,61 & 2,39 & 0,08 & 0,02 & 0,00 & 0,00 & 0,00 & 0,00 & 0,00 & 0,01 \\
\hline 6 & A 119897 & spona & lučík & 83,86 & 12,04 & 3,96 & 0,07 & 0,03 & 0,07 & 0,00 & 0,00 & 0,00 & 0,00 & 0,00 \\
\hline 7 & A 119896 & spona & kulička & 76,21 & 21,70 & 1,87 & 0,06 & 0,02 & 0,00 & 0,11 & 0,00 & 0,00 & 0,00 & 0,01 \\
\hline 8 & A 119896 & spona & lučík & 84,46 & 10,76 & 4,50 & 0,05 & 0,02 & 0,09 & 0,00 & 0,03 & 0,01 & 0,00 & 0,00 \\
\hline 9 & A 120023 & opasková garnitura & zápona & 77,23 & 14,05 & 6,63 & 0,08 & 0,03 & 2,01 & 0,00 & 0,00 & 0,01 & 0,00 & 0,00 \\
\hline 10 & A 120023 & opasková garnitura & kroužek & 73,71 & 16,89 & 3,76 & 0,06 & 0,04 & 5,37 & 0,08 & 0,00 & 0,03 & 0,00 & 0,00 \\
\hline 11 & A 120023 & opasková garnitura & kroužek & 87,29 & 7,88 & 4,47 & 0,14 & 0,04 & 0,12 & 0,00 & 0,11 & 0,00 & 0,00 & 0,00 \\
\hline 12 & A 120023 & opasková garnitura & závěsek & 77,10 & 19,26 & 3,23 & 0,06 & 0,02 & 0,13 & 0,08 & 0,06 & 0,02 & 0,00 & 0,00 \\
\hline
\end{tabular}

Tab. 1. Výsledky ED-XRF analýz prvkového složení kovového jádra artefaktů z hrobu H823; hodnoty uvedeny v procentech. Autor M. Kmošek.

Tab. 1. Results of ED-XRF elemental composition analysis of artefacts metal core from grave H823; values are given as a percentage. Author M. Kmošek. 


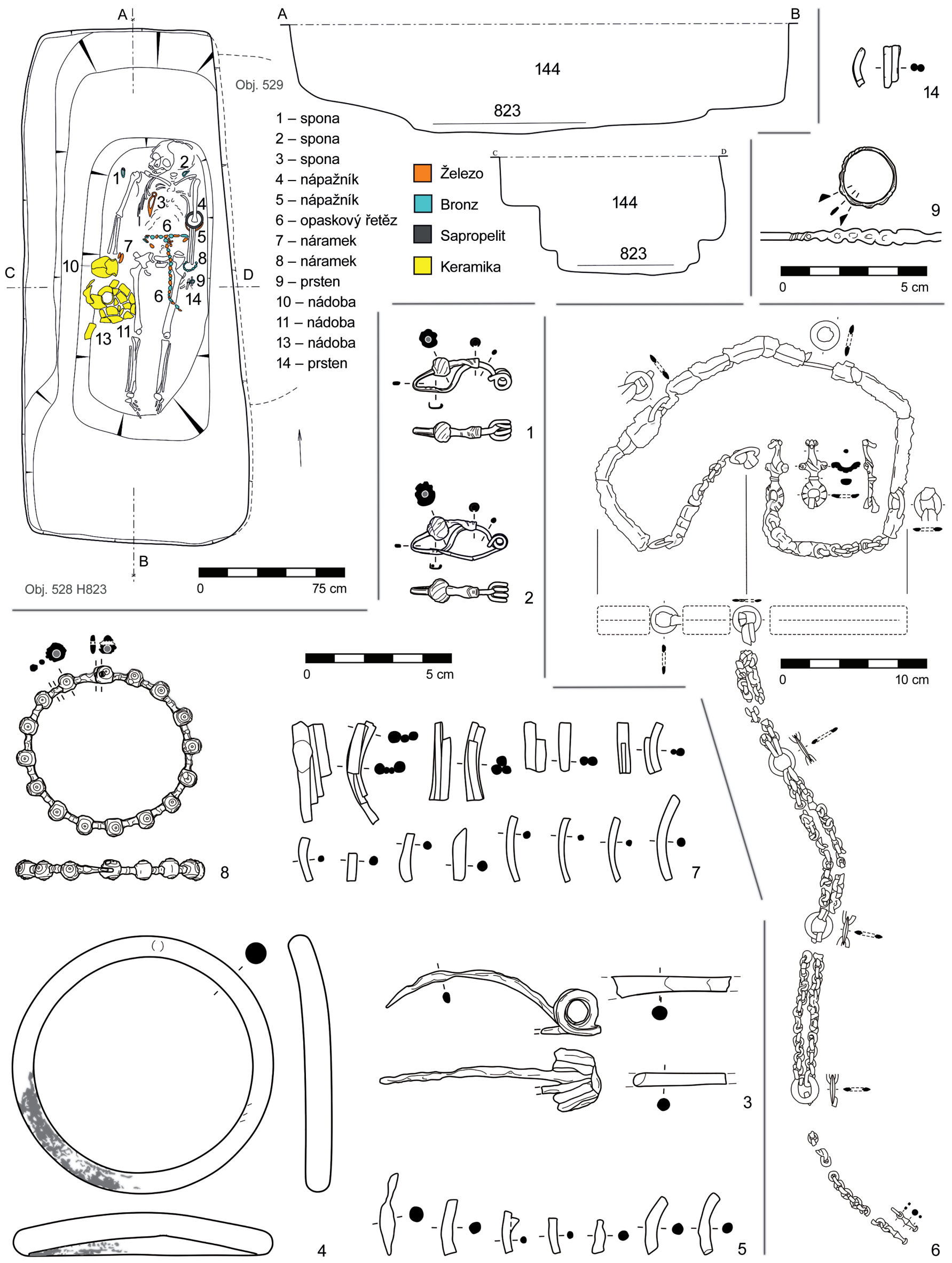

Obr. 6. Plán hrobu H823 s vyznačením hrobového inventáře a kresebná dokumentace př́ślušných kovových nálezů. Kresba M. Kmošek. Fig. 6. Plan of the grave H823 with location of the grave goods and drawing of the respective metal finds. Drawing by M. Kmošek. 


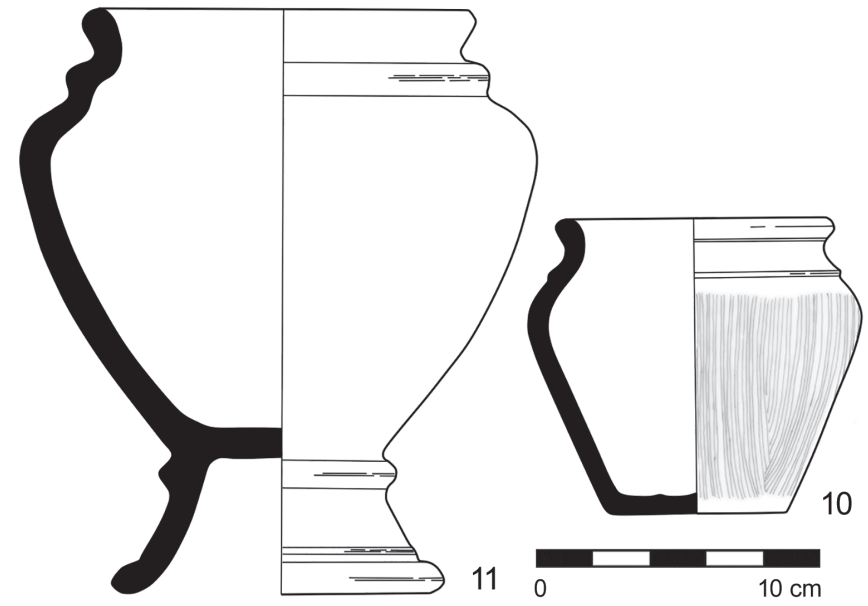

Obr. 7. Kresebná dokumentace keramických nálezů z hrobu H823. Kresba M. Michalíková.

Fig. 7. Drawing of ceramic finds from grave H823. Drawing by M. Michalíková.

Na povrchu opaskového řetězu se díky korozním procesům kovů dochovaly fragmenty textilií, které byly pracovně označeny jako fragmenty č. 1 (obr. 12: 3) a č. 2 (obr. 12: 4). Předměty organického původu, které se $\mathrm{v}$ době rozvoje koroze nacházely v těsné blízkosti kovového předmětu, se mohou zachovat ve třech různých formách: jako zbytky vlastního organického materiálu, jako zmineralizovaná forma původního organického materiálu (tzv. pseudomorfa) nebo jako otisk vnějšího povrchu původního organického předmětu v korozních vrstvách (Peška et al. 2006, 5, 38). V námi zkoumaném př́padě se jedná o tzv. pseudomorfu dochovanou díky poměrně agresivní korozi železa. Na povrchu železných kroužků horizontální části ženského opasku byly rozpoznány fragmenty textilu o velikosti $14 \times 7 \mathrm{~mm}$ u fragmentu č. 1 (obr. 12: 3) a $11 \times 6 \mathrm{~mm}$ u fragmentu č. 2 (obr. 12: 4). Ty byly podrobeny částečnému textilně-technologickému rozboru, kterého se laskavě ujala Mgr. Kristýna Urbanová. Vzhledem ke stavu dochování textilních fragmentů a silnému mechanickému poškození povrchu struktury nebylo možné provést všechna měření a určení korespondující s plným rozborem (například určení původní suroviny, materiálu, také určení torzí i samotné vazby je spíše pravděpodobné). Textilie na obou fragmentech byly pravděpodobně vyhotoveny v plátnové vazbě s torzí nití v obou př́ipadech Z (v osnově i útku, tedy obou soustavách, viz obr. 12: 3). Rozměr nití v obou soustavách se pohyboval od 0,7 do 0,9 mm. Fragmenty je možné vzhledem k jejich drobnosti velmi obtížné interpretovat. Pravděpodobně šlo o součást oděvu zemřelé, oděvní doplněk (obal, váček na předměty) nebo rubáš. Vzhledem k lokalizaci fragmentů se jeví jako nejpravděpodobnější poslední z uvedených možností.

Výbava hrobu obsahovala celkem tři spony - jednu větší jednoduchou železnou sponu (obr. 6:3) a pár identických gracilních bronzových spon (obr. 6: 1, 2; obr. 8: 1, 2). Neúplný železný exemplář (jehla a patka chybí) jednoduchého provedení z železného drátu s nevysokým klenutým lučíkem a vinutím tvořeným $2+2$ závity s vnější tětivou je obtížněji klasifikovatelný, svým charakterem však dobře odpovídá datování danému opaskovým řetězem. Dobře chronologicky zařaditelné jsou naopak bronzové spony s velkou, šikmo rýhovanou kuličkou na patce (obr. 8: 1), jež je k lučíku př́pevněna zdobenou svorkou; vinutí tvořené $2+2$ závity má vnitřní tětivu. Se sponami podobného charakteru se lze setkat i na jiných moravských pohřebištích (např. Brno-Maloměřice, hrob 17 - Čižmářová 2005 , 80, obr. 64:3), zpravidla ovšem nemají vnitřní tětivu a svorkou připojenou patku k lučíku - tento typ konstrukce se celkově na moravských pohřebištích vyskytuje zř́idka (např. Šlapanice, hrob 1/1934 - Čižmářová 2011, 156, tab. 53: 6, 7). Podobné spony se objevují také v hrobech na jihozápadním Slovensku, kde je lze přiřadit k typologické variantě BF-Hy, datované do stupně LT Cla-b (Bujna 2003, 58-59, obr. 25), v Čechách pokrývají podobné typy rozmezí LT B2b a LT C1a (Waldhauser ed. 1978, Abb. 53-54, 59).

Tělo bronzových spon bylo zhotoveno roztepáním výchozí tyčinky, kdežto kulička na patce byla pravděpodobně samostatně odlévána. Jednotlivé části spon jsou zhotoveny z olovnato-cínového bronzu s různorodým složením (tab. 1). Materiál těl obou spon si je vzájemně relativně podobný (vyšší obsah cínu, obdobné zastoupení olova a železa), kdežto materiál kuliček se znatelně liší především v obsahu olova. Vzhledem k nepř́iliš výhodným vlastnostem mechanického zpracování materiálu s vysokým zastoupením olova je jeho obsah ve sponách nečekaně vysoký. V kombinaci s cínem je však i tento materiál za dodržení specifických postupů mechanicky zpracovatelný (Nerantzis 2015, 334).

Garnitura kruhového šperku sestává ze dvou nápažníků na levé paži, doplněných bronzovým náramkem na levém zápěstí a bronzovým a železným prstenem na prstech téže končetiny. Soubor doplňuje železný náramek na pravém zápěstí. V podstatě odpovídá garnituře č. $9 \mathrm{v}$ rámci třídění M. Furmana $(2014,503)$, jež je definovaná na základě př́ítomnosti dvou nápažníků - sapropelitového a železného, a to v kombinaci bud' jen s nánožníky (jež v rousínovském hrobě absentují), nebo s dvojicí druhově rozdílných náramků. Tento typ kruhové garnitury se podle M. Furmana objevuje od přelomu stupňů LT B2 a C1 (Furman 2014, 503).

Atraktivní součást výbavy představuje bezpochyby také bronzový náramek z tenké tyčinky, na níž jsou upevněny odlévané kvádř́iky zdobené kroužky (obr. 6: 8, obr. 8: 3, 4). Podobné se objevují v moravských laténských hrobech, kde je podle ostatních součástí inventáře lze datovat opět do stupně LT B2/C1 (Brno-Bohunice, hrob 2 - Čižmářová 2011, tab. 2: 11; Brno-Maloměřice, hrob 52 - Čižmářová 2005, obr. 75: 2; Křenovice, hrob 1 - Čižmářová 2009, tab. 33: 9; Nechvalín, hrob 107 - Čižmářová 2017, tab. 26: 11; Přerov-Přredmostí - Čižmářová 2017, tab. 72: 3; Šlapanice, hrob 1/1934 - Čižmářová 2011, tab. 52: 14; Němčice nad Hanou "Za hájem“ - Čižmářová 2017, tab. 63: 3). Podobně jsou datovány i nálezy mimo území Moravy, např. Letky, hrob 27 (Waldhauser 1987, Taf. 14: 11) či ne úplně identický exemplář z Radovesic, hrob 31 (Waldhauser 1987, Taf. 25: 17, 18). Z moravských lokalit jsou známy i obdobné exempláře v železném provedení (Rajhrad, hrob 2014 - Čižmář, Kala 2015, obr. 4: 4; Šlapanice, hrob 4/1929 - Čižmářová 2011, tab. 53: 12; Slatina Čižmář, Lečbych 2013, 107), které lze datovat do stupně LT C1. Bronzový náramek byl vyroben ze samostatných odlévaných kvádříků upevněných na společné tyčince s čepovým spojem (obr. 8: 4). Kvádříky byly přichyceny roztepáním tyčinky směrem ke kvádř́íkům, čímž mezi nimi vznikla nevýrazná příčná žebra (obr. 8: 3). Popsaná technologie výroby se projevila i dualitou prvkového složení jednotlivých částí (tab. 1). Tři analyzované kvádř́ḱky jsou zhotoveny z přibližně shodného materiálu s vysokým obsahem olova (průměrně 30,2\%), nižším obsahem cínu (průměrně 3,38 \%) a zvýšeným obsahem bismutu (průměrně $0,25 \%$ ), což je materiál svými vlastnostmi velmi vhodný k odlévání. Naopak tyčinka je vyrobena z nízkolegovaného bronzu vhodného k mechanickému zpracování za studena, kde na rozdíl od veškerých ostatních artefaktů v souboru převažuje obsah cínu nad olovem. U tyčinky je také netypicky vysoké zastoupení železa a arsenu.

Další výraznou součástí hrobové výbavy je sekundárními procesy ${ }^{5}$ mírně deformovaný sapropelitový nápažník (obr. 6: 4, 

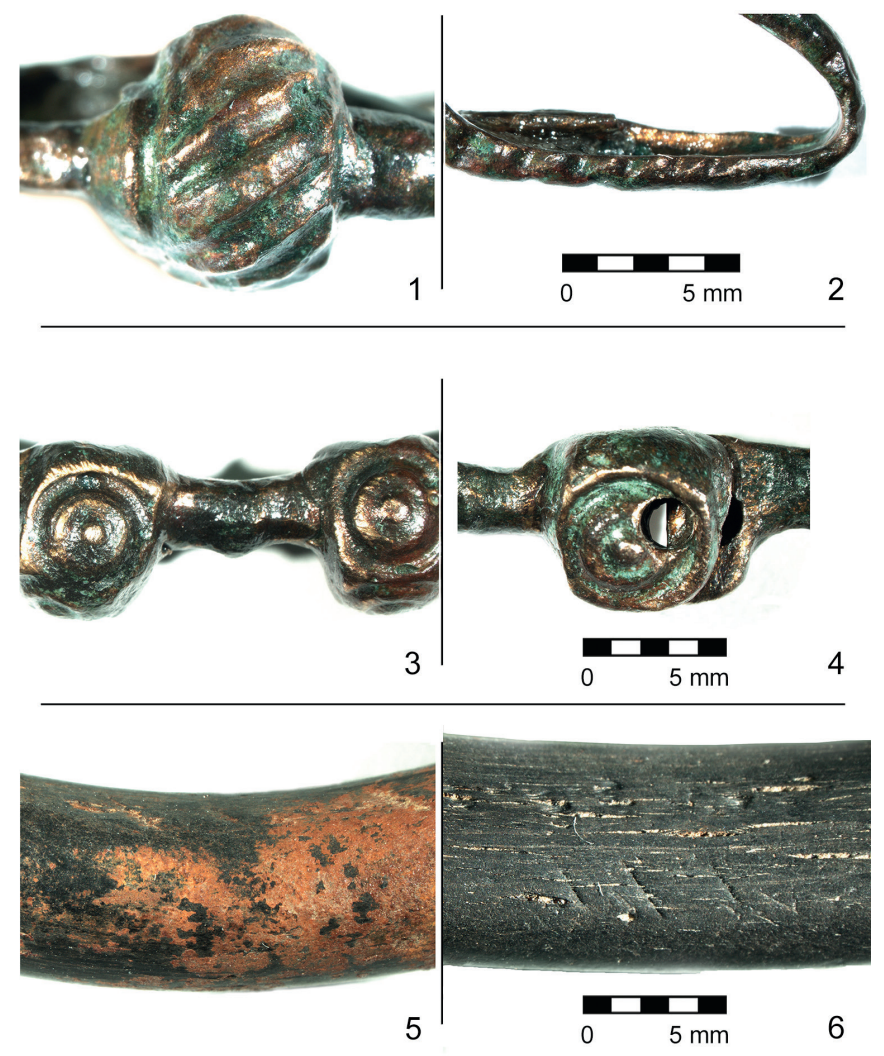

Obr. 8. Mikroskopické snímky artefaktů z hrobu H823; 1 - zdobená kulička na patce spony A 119897; 2 - výzdoba diagonálními rýhami na zachycovači spony A 119897; 3 - vytepaná př́ícná žebra mezi kvádříky na náramku A 119898; 4 - čepový spoj náramku A 119898; 5 - korozní produkty železa na sapropelitovém nápažníku A 119904; 6 - rovnoběžné diagonální zářezy na vnitřní straně sapropelitového nápažníku A 119904. Foto M. Kmošek.

Fig. 8. Microscopic images of artefacts from grave H823; 1 - decorated knob of the fibula A 119897; 2 - diagonal grooved decoration on the catch-piece of the fibula A 119897; 3 - hammered transverse ribs between cuboids on the bracelet A 119898; 4 - pin joint of the bracelet $A$ 119898; 5 - iron corrosion products on sapropelite armring A 119904; 6 - parallel diagonal grooves on the inside of the sapropellite armring A 119904. Photo by M. Kmošek.

obr. 8: 5, 6). Tento druh šperku je ve středoevropském prostoru velmi oblíbený, o čemž svědčí nejen četnost jeho výskytu, ale i kombinace s dalšími náramky/nánožníky, s nimiž se společně objevuje. Hodnota šperku spočívala zřejmě především v symbolickém významu černého materiálu samotného, který snad imitoval antický gagát (Venclová 1995, 559). Počátek zpracování švartny/sapropelitu, potažmo jeho výskytu v laténských hrobech, by podle N. Venclové mohl spadat do období přelomu stupňů LT B1 a LT B2, přičemž jeho nejstarší výskyt je logicky zaznamenán v české oblasti, kde se nacházejí surovinová ložiska (Venclová 2001, 112, obr. 65). Švartnový šperk je na Moravě celkem běžnou součástí výbavy jak mužských, tak především ženských kostrových hrobů stupně LT B2 a jeho mladší výskyt je zde zatím doložen pouze sídlištními nálezy (Meduna 1980, 118). Zvláště u dřive nalezených celků nebývá vždy uvedeno umístění švartnového kruhu na kostř̌e, je však zjevné, že především kruhy větších rozměrů sloužily jako nápažníky, jako je tomu i u námi pojednávaného celku.

Železný hladký nápažník se dochoval v nerekonstruovatelných fragmentech (obr. 6: 5), jde o jednoduchý typ zhotovený z železné tyčinky, vzhledem ke stavu dochování nelze říci, zda pouze s přeloženými konci či zda je tyčinka násobně stočená. Ve fragmentech se dochoval také další železný kruh - náramek z pravého zápěstí (obr. 6: 7). Tento byl však nejméně čtyřikrát stočen, jak dokládá jeden ze zachovalých fragmentů. Oba kruhy lze podle J. Bujny datovat do stupně LT B2/C1 (Bujna 2005, obr. 89), totéž platí i o nálezech moravských (např. Čechůvky Čižmářová 2017, tab. 56: 2; Křenovice, hrob 21 - Čižmářová 2009, tab. 41: 1; Střelice, hrob 1 - Čižmářová 2011, tab. 51: 13, 15; Mistř́n, hroby 2 a 8 - Čižmářová 2017, tab. 10: 5, 13: 7; Nechvalín, hroby 108 a 129 - Čižmářová 2017, tab. 27: 4, 30: 13; Šlapanice, hrob 6/1999 - Čižmářová 2011, tab. 54: 7).

Garnituru kruhového šperku z výbavy pohřbené ženy doplňují dva prsteny (obr. 6: 9, 14). Tyto drobné ozdoby se v keltském prostředí sporadicky objevují od 5. století př. Kr. jako mužský šperk prezentující výjimečné postavení nositele, pravděpodobně pod působením vlivů z mediteránní oblasti. Ve 4. století se prsten stává spíše záležitostí ženského kruhového šperku, je vyráběn z bronzu, ale i ze železa, posléze výjimečně i ze sapropelitu; v některých případech se prsteny v hrobech vyskytují i ve větším počtu (souhrnně Furman 2014, 496). V rousínovském hrobě byly oba prsteny nalezeny ve funkční pozici na prstech levé ruky. Prosté železné kroužky se na moravských pohřebištích vyskytují jak samostatně (např. Křenovice, hroby 26 a 30 - Čižmářová 2009, tab. 41: 15, 42: 8), tak i společně s dalším, většinou bronzovým exemplářem (např. Blučina, hrob 20 - Čižmářová 2011, tab. 29: 19-21). Bronzové prsteny se vyskytují v řadě variant, od jednoduchých drátěných, někdy v sedlovém provedení, přes tzv. snubní prsteny ke zdobeným exemplářům, přičemž některé lze jen stěží rozpoznat od novověkých artefaktů. Exempláre se zdobenou horní (viditelnou) částí lze podle J. Bujny datovat opět do stupně LT B2/C1, některé i do stupně LT Cla-b (Bujna 2005, obr. 75); tomu odpovídají i moravské nálezy (Lovčičky - Čižmářová 2013, tab. 27: 14; Ponětovice, hrob 32 - Čižmářová 2011, tab. 47: 2). Povrchové měření bronzového prstenu (tab. 2) prokázalo, že je stejně jako ostatní bronzové předměty v souboru vyroben z olovnato-cínového bronzu. Přesné kvantitativní zastoupení cínu a olova ve slitině však není možné vzhledem k povrchové analýze určit. Složením se však prsten nejvíce přibližuje materiálu tyčinky výše uvedeného náramku, tedy nízkolegovanému bronzu.

\begin{tabular}{lllllllll}
\hline Inv. č. & Předmět & Část předmětu & $\mathbf{C u}$ & $\mathbf{P b}$ & $\mathbf{S n}$ & $\mathbf{S b}$ & $\mathbf{N i}$ & $\mathbf{F e}$ \\
\hline \multirow{2}{*}{ A 119899} & prsten & čelnístrana & 79,7 & 8,6 & 11,1 & 0,2 & 0,1 & 0,0 \\
\hline
\end{tabular}

Tab. 2. Výsledek ED-XRF analýzy prvkového složení povrchu prstenu A 119899 z hrobu H823; hodnoty uvedeny v procentech. Autor M. Kmošek.

Tab. 2. Result of ED-XRF elemental composition surface analysis of ring A 119899 from grave H823; values are given as a percentage. Author M. Kmošek.

Soubor kovových předmětů je doplněn dvěma keramickými nádobami (obr. 7: 10,11). Jedna z nich je váza na nožce, tvar na moravských pohřebištích nepříliš častý. Analogické nálezy shromáždili již J. Meduna s I. Peškařem (1992, 234-243, Abb. 24: 2-5, 25: 5, 26: 7, 27: 1, 29: 5). Podle chronologického rozboru př́slušných hrobových celků se tyto tvary objevují na moravských pohřebištích od LT B1b do LT Cla (Meduna, Peškař 1992, 242-243); tato součást inventáře tedy jeho přesnějšímu datování nenapomáhá. Podobně další nádoba, vázovitý tvar bikónicky profilovaného těla s maximální výdutí v horní polovině výšky, nevybočuje z typické tvarové škály moravské keramiky, jakou známe z řady dalších laténských pohřebišt, třebaže je poněkud menšího a robustnějšího provedení (např. Lovčičky, hrob 12 - Čižmářová 2013, tab. 28: 14; Lysice - Čižmářová 2013, tab. 14: 3; Marefy, hrob 16 - Čižmářová 2013, tab. 36: 6; Nížkovice, hrob 14 - Čižmářová 2013, tab. 42: 6; Slavkov, rozrušené hroby - Čižmářová 2013, tab. 55: 16; a řada dalších). 
Inventář kostrového ženského hrobu H823 lze srovnat s řadou celků z jiných moravských pohřebišté, v nichž se analogicky vyskytují jak jednotlivé předměty (viz výše), tak i jejich kombinace - jsou to např. Brno-Maloměřice, hrob 17 (bronzová spona, fragmenty opaskového řetězu - Čižmářová 2005, obr. 64: 3, 5), Brno-Maloměřice, hrob 52 (bronzový náramek, fragmenty opaskového řetězu - Čižmářová 2005, obr. 75: 2, 5, 6), Šlapanice, hrob 1/1934 (spony, bronzový náramek - Čižmářová 2011, tab. 52: 14, 53: 6, 7). Všechny tyto celky lze zařadit do rozmezí stupně LT B2/C1 a lze tak datovat i inventář rousínovského hrobu H823.

\section{Průzkum a specifika konzervátorského ošetření kovových artefaktů}

Kovové artefakty ze dvou mimořádných hrobů z Rousínova byly fotograficky a mikroskopicky zdokumentovány a důsledně konzervátorsky ošetřeny, ${ }^{6}$ železné předměty byly podrobeny rentgenografickému průzkumu. Předměty ze slitin mědi byly podrobeny rentgenfluorescenční analýze prvkového složení. Hlavní výsledky průzkumu př̀dmětů jsou popsány níže.

Pro mikroskopický průzkum a dokumentaci byl použit binokulární mikroskop Nikon SMZ 1500 (obr. 8; obr. 11: 3, 4; obr. 12: 3, 4). Rentgenografický průzkum železných předmětů byl proveden na základně Archeologického ústavu AV ČR, Brno, v. v. i.v Mikulčicích pomocí rentgenové lampy ERESCO 160 MF4-R se snímáním na radiografický film (obr. 9). Prvkové složení předmětů ze slitin mědi z hrobu H823 bylo zkoumáno metodou rentgenové fluorescence (ED XRF) na Archeologickém ústavu ČR, Brno, v. v. i. Ze čtyř předmětů ${ }^{7}$ bylo odebráno celkem 12 vzorků kovového jádra jednotlivých částí (lokalizace míst odběru viz obr. 10). Vzorky kovového jádra byly odebrány odvrtáním HSS-TiN spirálovým vrtákem o průměru $1 \mathrm{~mm}$. Analýza vzorků byla provedena na př́stroji ElvaX Pro (Ag rentgenka, mód $\mathrm{Cu}$, doba měření 120 sekund, urychlovací napětí 45 a $10 \mathrm{kV}$, kolimátor $4 \mathrm{~mm}$ ) a data byla vyhodnocena v softwaru ElvaX prostřednictvím módu Cu (výsledky viz tab. 1). U bronzového prstenu (A 119899) nebylo možné kvůli subtilnosti artefaktu provést odběr vzorku kovového jádra, proto byl podroben

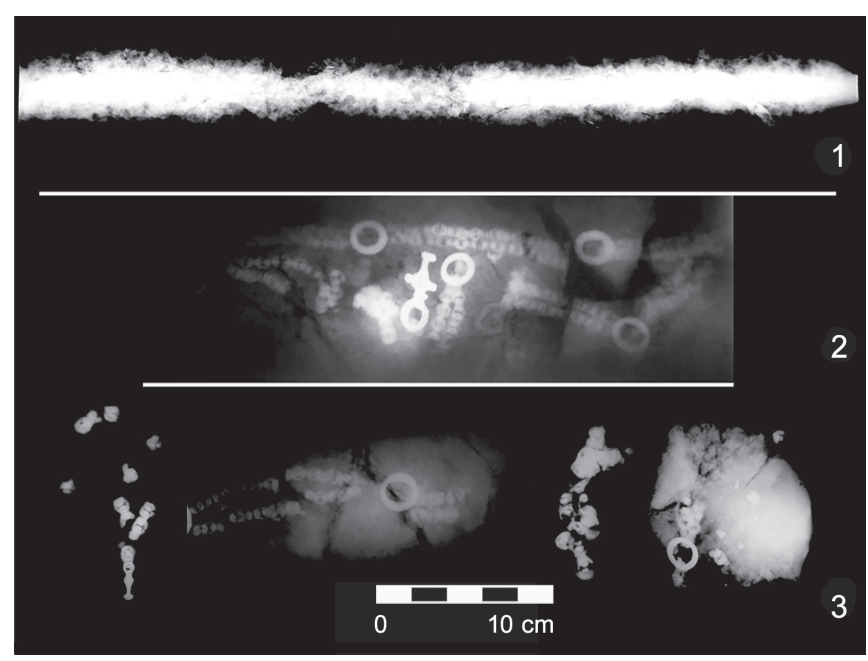

Obr. 9. Rentgenografické snímky předmětů vyzvednutých v bloku; 1: část meče sfragmenty pochvy (A 120025, A 120027) z hrobu H821; 2: blok zeminy s vrchní horizontální části řetězového opasku A 120023; 3: čtyři bloky zeminy s vertikální části řetězového opasku A 120023. Autoři M. Chovanec, M. Kmošek.

Fig. 9. X-ray images of artefacts extracted in the block; 1: part of the sword with scabbard fragments (A 120025, A 120027) from grave H821; 2: a soil block with the upper horizontal part of the chain belt A 120023; 3: four soil blocks with the vertical part of the chain belt A 120023. Authors M. Chovanec, M. Kmošek. alespoň povrchovému měření pomocí ručního spektrometru Niton XL3t 980 (Rh rentgenka, mód General metals, doba měření 30 sekund, urychlovací napětí 50 kV; výsledky viz tab. 2).

Prvková analýza předmětů ze slitin mědi z hrobu $\mathrm{H} 823$ (tab. 1 a 2) prokázala, že zkoumané předměty jsou zhotoveny z olovnato-cínového bronzu, převážně s převládajícím obsahem olova. Ve slitině se objevuje také nízké zastoupení příměsí antimonu, niklu a železa a v některých př́padech také bismutu, zinku, kobaltu, arsenu či stříbra. Individální poznámky ke složení jednotlivých analyzovaných předmětů jsou uvedeny v textu výše. Při vyhodnocení a interpretaci výsledků předložených analýz, kde se objevuje zvýšený obsah olova, je třeba brát v potaz nedokonalou rozpustnost olova v mědi, která způsobuje heterogenní rozložení olova $\mathrm{v}$ předmětech. Olovo totiž (například oproti cínu nebo zinku) nevytváríi s mědí tuhý roztok, ale koncentruje se na hranicích zrn, což způsobuje jeho odlišné koncentrace na různých místech artefaktu, jež se mohou lišit až v řádu jednotek procent (Chakrabarti, Laughlin 1984). Při porovnávání výsledků analýz je třeba brát v potaz, že složení kovového jádra (tab. 1) se přibližuje původně použitému materiálu, kdežto povrchová měření (tab. 2) jsou zatížena jistým nezanedbatelným zkreslením způsobeným především korozními procesy a znečištěním povrchu (Pollard, Bray 2014, 220). Např́iklad obsah olova a cínu na povrchu bývá oproti složení jádra často výrazně nadhodnocen v řádu jednotek až desítek procent (Kmošek 2019, 20-22).

Při srovnání s dosud provedenými analýzami na artefaktech z mladší doby železné je zřejmé, že závěry zjištěné na souboru z Rousínova zapadají do charakteru slitin používaných v uvedeném období. Především jde o charakteristický trend mladší doby železné spojený s převládajícím užíváním bronzů se značným množstvím olova. Markantní nárůst specifických olověných bronzůje pozorován především od stupně LT B2 (Frána et al. 1997), což se shoduje s výše uvedeným typologickým datováním nálezového celku H823. Výrazné zavedení olověného bronzu má svůj důvod zřejmě v technologicky výhodných vlastnostech této slitiny, především s ohledem na její slévatelnost. Slitina se zvýšeným obsahem olova se projevuje redukcí viskozity, snížením teploty tání slitiny a zvýšením hmotnosti slitiny. Př́ítomnost olova ve slitině (např́iklad oproti čisté mědi) způsobuje rychlejší mechanické zpevňování tvářením za studena, ale zároveň svou křehkostí umenšuje tvárnost (vznik trhlin, povrchových defektů). Přesto je možné při dodržení správného postupu tyto slitiny mechanicky zpracovávat (Nerantzis 2015, 334). U analyzovaných artefaktů je možné sledovat markantní kontrolu výrobců nad složením a s tím spojenými vlastnostmi slitiny především u bronzového náramku. Zřejmě odlévané kvádř́íky jsou zhotoveny ze slitiny s vysokým obsahem olova, kdežto tepaná tyčinka je z nízkolegovaného bronzu vhodného k mechanickému zpracování. U dvojice spon je kontrola nad složením užitého materiálu výrazně nižší a není možné ji vysvětlit čistě technologickými důvody. Nehomogenitu materiálu u článků opaskového řetězu je možné vysvětlit masovou výrobou a využíváním těchto komponent.

Konzervátorské ošetření probíhalo u většiny kovových artefaktů standardním způsobem pro př́ílušné materiály (Benešová et al. 2011) a jeho úplný popis neodpovídá primárnímu zaměření předložené studie. $\mathrm{Z}$ toho důvodu jsou níže popsána pouze vybraná specifika zásahů, které si vyžádala konzervace tři komplexnějších předmětů, tedy železného meče s pochvou a kopí ze žárového hrobu H821 a bimetalického opaskového řetězu z kostrového hrobu H823.

Železný meč s pochvou a železné kopí z hrobu H821 byly ošetřeny srovnatelným konzervátorským postupem standardním pro slitiny železa (Benešová et al. 2011). Meč s pochvou byl před zásahem rentgenograficky prozkoumán (obr. 9: 1). Specifický 


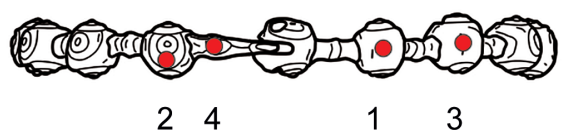

A 119898

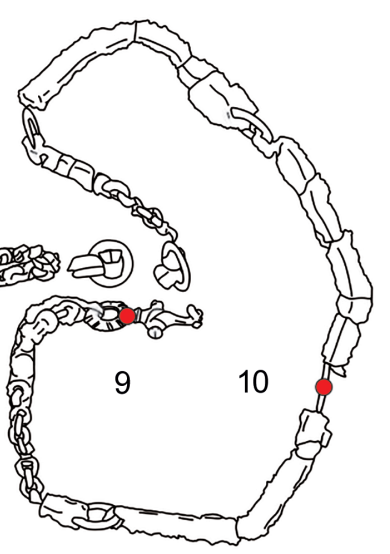

Obr. 10. Lokalizace míst odběru vzorků kovového jádra artefaktı̊ z hrobu $\mathrm{H} 823$, bez měř́tka. Kresba M. Kmošek.

Fig. 10. Location of sampling spots of artefacts metal core from grave $\mathrm{H} 823$, without scale. Drawing by M. Kmošek.
12

6

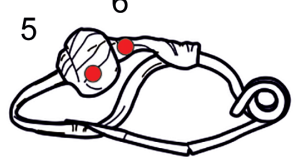

A 119897

\section{8}

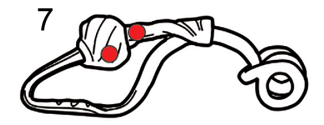

A 119896 př́stup si vyžádal zásah na fragmentech pochvy meče (obr. 4: 3), které byly při výzkumu intaktně vyzvednuty spolu $\mathrm{s}$ mečem (obr. 11: 1). Kvůli mechanickému zajištění a vizuální celistvosti byly veškeré samostatné fragmenty pochvy připevněny pomocí kyanoakrylátového lepidla na speciálně vytvořený podklad z polymethylmethakrylátu (plexisklo) o síle $4 \mathrm{~mm}$, který svými rozměry a tvarem odpovídá zachovalému stavu meče. Po dokončení konzervace byly adjustované fragmenty pochvy (A 120027) uloženy spolu s mečem (A 120025) a opaskovým řetězem (A 120024) do speciálně vytvořeného lůžka z mirelonu ( $\mathrm{PE}$ ) podle polohy nálezů in situ (obr. 1: 2). Při mikroskopickém průzkumu meče v průběhu čištění byly v místě čepele zjištěny také lokálně zachovalé fragmenty okrajů pochvy přikorodované $\mathrm{k}$ povrchu meče (obr. 11:3).

Železné kopí (A 120026) bylo v polovině tuleje příčně zlomeno a mělo odlámanou část čepele, z níž se zachovalo několik drobných samostatných fragmentů (obr. 11: 5). Odlomené části byly adjustovány na př́slušná místa pomocí kyanoakrylátového lepidla (obr. 11: 6). Při mikroskopickém průzkumu předmětu $\mathrm{v}$ průběhu jeho čištění byl na spodní části tuleje identifikován a zdokumentován unikátní rytý dekor (obr. 11: 4). Ten byl šetrně odhalen a zviditelněn velmi jemným čištěním pomocí mikrotryskání skleněnou balotinou za nízkého tlaku (200 kPa). Je možné předpokládat, že dekor mohl zasahovat i na vrchní část tuleje, která je však u předmětu špatně zachována.

Při konzervaci opaskového řetězu z ženského hrobu H823 (A 120023) bylo nutné zohlednit především bimetalický materiál, křehkost drobných železných kroužků i lokálně zachovalé pozůstatky textilií. Opaskový řetěz byl v terénu vzhledem ke svým rozměrům odebrán celkem v pěti blocích spolu s okolní zeminou. Největší blok obsahoval vrchní horizontální část opasku upevněnou původně kolem pasu (obr. 12: 1). Další bloky zahrnovaly jednotlivé fragmenty vertikální části opasku. Před konzervací byly jednotlivé bloky podrobeny rentgenografickému průzkumu (obr. 9: 2, 3). Vizuálním a mikroskopickým průzkumem byly na vnitřní straně horizontální části opasku identifikovány pozůstatky textilií (více viz výše, obr. 12: 3, 4). Při rozebírání bloků byla průběžně pečlivě udržována poloha, směr i orientace jednotlivých fragmentů, aby je bylo možné zpětně složit do celistvého tvaru (obr. 12: 2). Fragmenty byly průběžně lepeny kyanoakrylátovým lepidlem, aby nedošlo $\mathrm{k}$ př́lišné fragmentarizaci artefaktu. Zachovalé lomové plochy fragmentů horizontální části opasku dovolovaly zrekonstruovat oválný tvar této části opasku o obvodu cca $60 \mathrm{~cm}$ (obr. 12: 5). Na závěr byly fragmenty vrchní a spodní části opasku uloženy do lůžka z mirelonu (PE), speciálně vytvořeného podle jejich nálezového stavu (obr. 12: 5).

\section{Antropologická analýza kosterních pozůstatků}

Pozůstatky z obou hrobů se zachovaly relativně špatně. Ze žárového pohřbu H821 je to jen několik drobných fragmentů bez větší výpovědní hodnoty, z kostrového pohřbu H823 se sice zachovaly fragmenty všech částí skeletu, ten je však celkově nutné hodnotit jako nekompletní a poměrně silně poškozený dekompozičními procesy. Jen ojedinělé drobné zlomky se potom zachovaly z kostřričky novorozence (H822). To vše pochopitelně limituje možnosti antropologického hodnocení.

Vzhledem k faktu, že dosud nebylo dokončeno kompletní antropologické hodnocení všech souborů vyzvednutých na tomto pohřebišti (nemluvě o pozůstatcích zničených postupem investora, které zůstaly na místě), je obtížné zasadit i omezené poznatky získané z obou pohřbů do širšího kontextu. Jen zcela předběžně je možné konstatovat, že jejich kvantitativní ani kvalitativní ukazatele pravděpodobně nijak nevybočují z celkového antropologického obrazu pohřebiště.

Žárový pohřeb H821 byl v rámci možností hodnocen dle metodiky doporučené M. Dokládalem (1999). Odhad pohlaví byl na základě přítomných a hodnotitelných morfologických znaků proveden podle standardních postupů (Knussmann 1988). Pro odhad dožitého věku byla vzhledem ke špatné zachovalosti skeletu použita jen metoda posouzení obrusu chrupu (Lovejoy 1985), v př́padě novorozence byl hodnocen stav mineralizace zlomkovitě zachovalých zubů (Vlček 1994), a jen orientačně odhadnuty délky poškozených dlouhých kostí (Stloukal, Hanáková 1978). 
Dva mimořádné hroby z laténského pohřebiště v Rousínově • Čižmář, I., Mikulková, B., Kmošek, M., Chovanec, M., Kala, J.

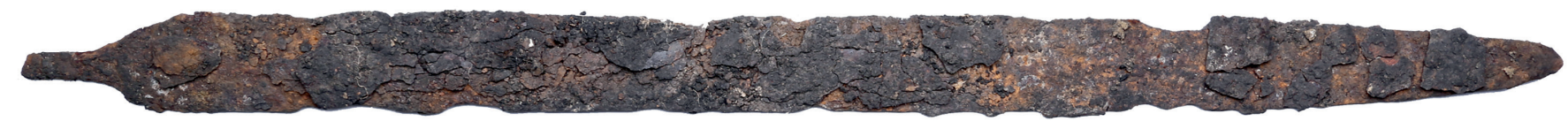

1
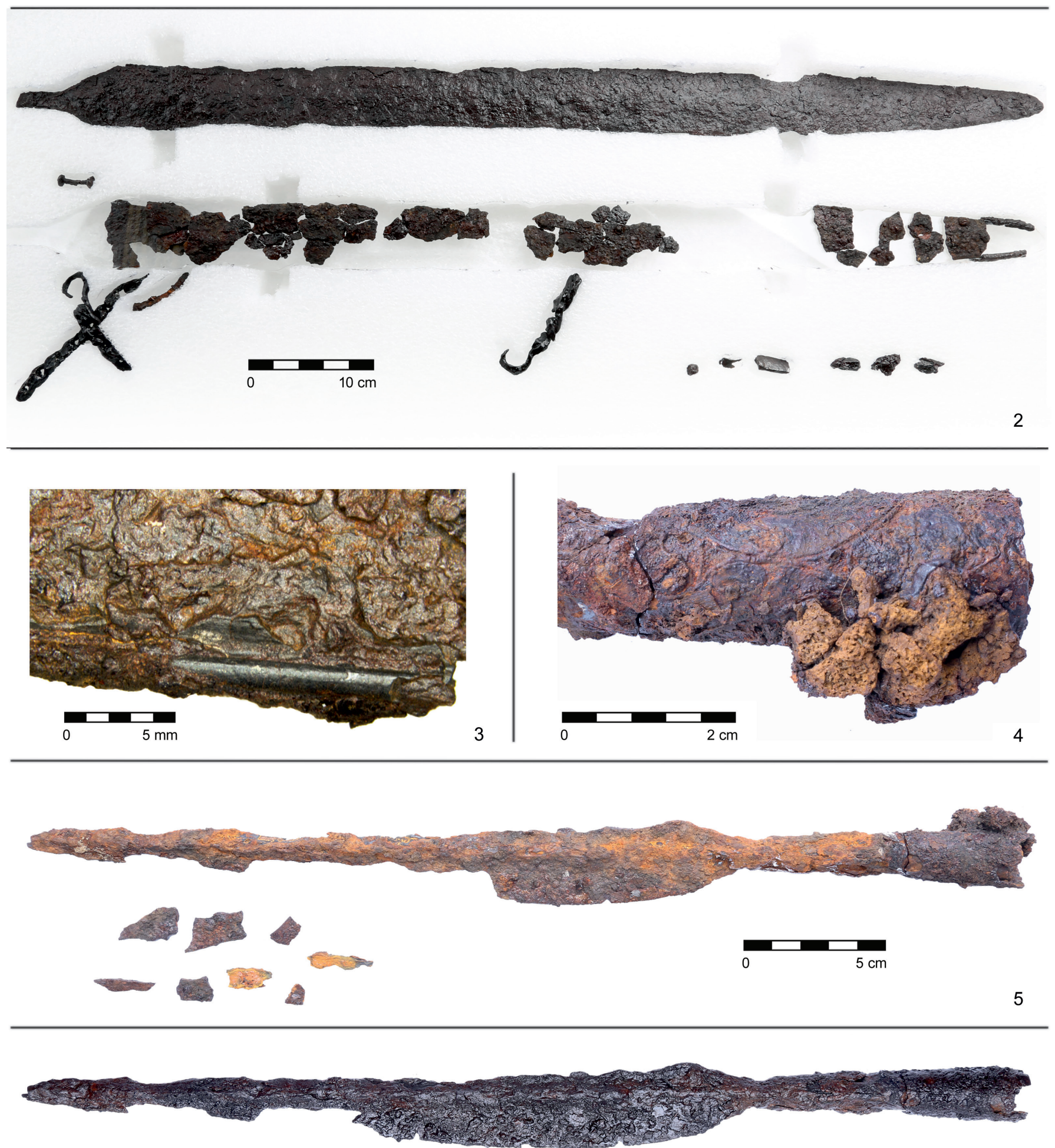

Obr. 11. Dokumentace konzervace železného meče a kopí z hrobu H821; 1 - meč s fragmenty pochvy před konzervátorským zásahem; 2 - meč s fragmenty pochvy a opaskového řetězu po konzervaci v lůžku z mirelonu; 3 - mikroskopický snímek fragmentu okraje pochvy přikorodovaného k meči; 4 - detail ryté lineární výzdoby na tuleji listu kopí po základním očištění; 5 - list kopí před konzervátorským zásahem; 6 - list kopí po konzervaci a kompletaci. Foto M. Chovanec.

Fig. 11. Conservation documentation of iron sword and spear-head from grave H821; 1 - sword with scabbard fragments before conservation; 2 - sword with fragments of scabbard and chain-belt after conservation in a mirelon casing; 3 - Microscopic image of the scabbard's edge fragment corroded to the sword blade; 4 - detail of the engraved linear decoration on the spear-head socket after basic cleaning; 5 - spear-head before conservation; 6 - spear-head after conservation and assembling. Photo by M. Chovanec. 

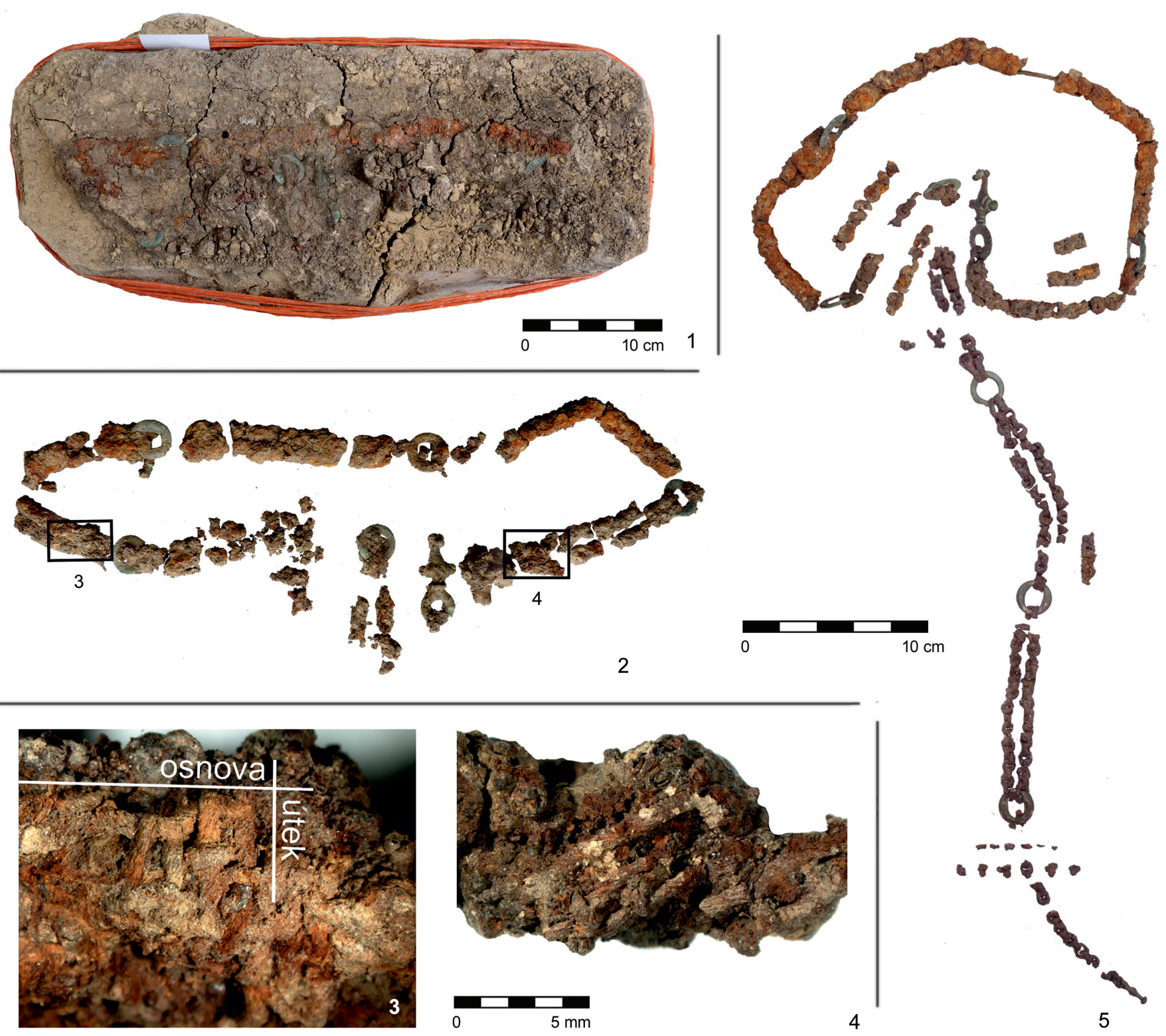

4

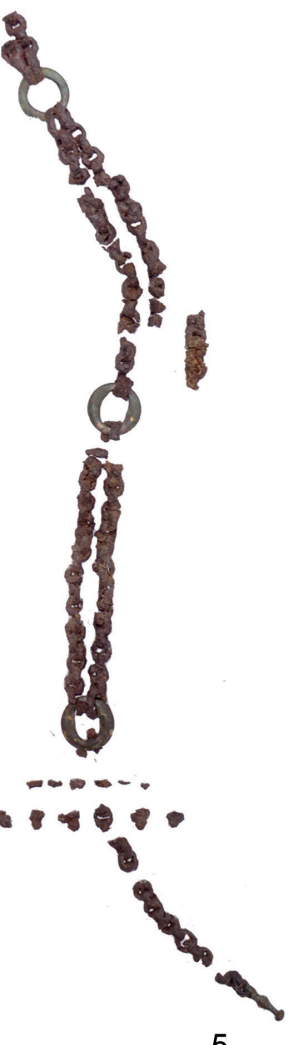

Obr. 12. Dokumentace konzervace bimetalického opaskového řetězu z hrobu H823; 1 - vrchní část opasku odebraná v bloku zeminy; 2 - vrchní část opasku rozebraná z bloku; 3, 4 - mikroskopické snímky pozůstatků textilií na vrchní části opasku (fragment 1 a 2); 5 - kompletní opasek po konzervaci a kompletaci. Foto M. Kmošek.

Fig. 12. Conservation documentation of bimetallic chain-belt from grave H823; 1 - the upper horizontal part of the belt extracted in the soil block; 2 - the upper part of the belt disassembled from the soil block; 3, 4- microscopic images of the fabric remains on the upper part of the chain-belt (fragment 1 and 2); 5 - chain-belt after conservation and assembling. Photo by M. Kmošek.

\section{Hrob H821}

Z hrobu pochází asi dvacet drobnějších fragmentů spálených kostí. Žádný zlomek se nepodařilo spolehlivě identifikovat a potvrdit tak jeho lidský původ. Př́ítomny jsou fragmenty lebky i postkraniálního skeletu, které převažují. Jejich vzhled odpovídá stupni spálení IV, přičemž jsou poměrně křehké. Největší zlomek, pocházející z robustní diafýzy dlouhé kosti, má velikost $44 \times 12 \mathrm{~mm}$, ostatní jsou podstatně menší. Pozůstatky prošly žárem o teplotě $550-650^{\circ} \mathrm{C}$. Antropologicky nelze potvrdit, zda jsou lidského původu a přesněji nelze stanovit ani demografické parametry. Pravděpodobně však náleží dospělému jedinci.

\section{Hrob H822}

Vyzdviženy byly špatně zachovalé, silně fragmentarizované a nekompletní drobné úlomky dětské kostry. Z lebky je zachována pravá skalní kost, několik velmi drobných úlomků plochých kostí mozkovny a pět základů mléčných zubů (tři stoličky a dva řezáky).
Z postkraniálního skeletu jsou zachovány sporé zlomky z osového skeletu i kostí končetin, žádná kost ale není kompletní. Relativně nejzachovalejší, resp. alespoň rámcově identifikovatelné, jsou fragmenty stehenních kostí, levé klíční kosti a obou kostí pravého (?) předloktí. Základy mléčných zubů jsou mineralizovány na stupeň II, délku dlouhých kostí nelze změřit, relativně nejzachovalejší kosti předloktí však zřejmě délkou nepřesáhly $6 \mathrm{~cm}$. Lze tedy odhadnout, že pohřbeným byl pravděpodobně novorozenec. Vzhledem $\mathrm{k}$ nízkému věku a zachovalosti nelze jeho pohlaví odhadnout.

\section{Hrob $\mathrm{H} 823$}

Pozůstatky z kostrového hrobu tvoří špatně zachovalé, fragmentarizované a nekompletní kosterní pozůstatky dospělého člověka (obr. 13: 1). Povrchová eroze je silná, kosti mají světlejší šedožlutou barvu.

Lebka je silně fragmentarizovaná a nekompletní (obr. 13: 2). Dekompozičními procesy byla prakticky strávena celá zadní část 
mozkovny, ze které jsou zachovány jen drobné rozpadající se fragmenty. Nejzachovalejším celkem lebky je obličejová část s torzem čelní kosti a dolní čelist, poškozená na obou ramenech. Morfologické znaky jsou z větší části nehodnotitelné; dobře patrná je však poměrně výrazně vyklenutá glabela kontrastující s nevyvinutými arc. superciliares a téměř přímým nasofrontálním přechodem. Lícní kosti jsou střední stavby i modelace, dolní čelist je gracilní a nevýrazně modelovaná. Ve stropech obou očnic, výrazněji vlevo, jsou prrítomna cribra orbitalia porotického typu (obr. 13: 4).

V horní čelisti původně kompletní stálý chrup, intravitálně byla kazem zcela zničena korunka druhé pravé stoličky, v místě tř̀etí stoličky vpravo je pouze mohutné, vně otevřené polokulovité zánětlivé ložisko o průměru cca $1 \mathrm{~cm}$ (obr. 13: 3). Postmortálně je ztracen levý stř̌ední řezák. Obrus odpovídá fázi $\mathrm{E}$ až F. V dolní čelisti nebyly oboustranně prořezány třetí stoličky, první stolička vlevo byla ztracena dlouho před smrtí, alveol je zcela resorbován. Všechny čtyřri řezáky byly patrně postmortálně vylomeny, v alveolu je zachován pahýl kořene druhého levého, zbývající tři se zachovaly volně. Obrus odpovídá fázi $\mathrm{F}$.

Postkraniální skelet je silně nekompletní. Až na několik úlomků oblouků hrudních obratlů a sedmi či osmi drobných fragmentů žeber (většinou z levé části hrudníku) se nezachoval osový skelet. Z kostry horní končetiny jsou zachovány fragmenty obou klíčních kostí a lopatek, větší části diafýz pažních kostí a všech kostí předloktí. Přestože jsou všechny velmi špatně zachovalé, jsou kosti levé strany v relativně lepším stavu. Možno-li vůbec soudit, byly velmi gracilní stavby s nevýrazným svalovým reliéfem. Na distálním konci fragmentu pravé kosti vřetenní je výrazná stopa zelené patiny, stejně jako na jediném dochovaném prstním článku ruky. Z kostí pánevních jsou zachovány dva menší fragmenty, jeden z oblasti inc. ischiadica major a fac. auricularis pravé kosti, druhý je stranově neidentifikovatelný zlomek okraje acetabula. Morfologické znaky nejsou spolehlivě hodnotitelné, zdá se však, že inc. ischiadica major je spíše širší, tvaru písmene V. Zachovány jsou obě poškozené stehenní kosti, levá patella a větší části diafýz kostí bérců, zachovalejší vpravo. Všechny kosti jsou gracilní stavby a nevýrazné modelace. Z kostry nohou jsou zachovány jen silně poškozené drobné zlomky obou hlezenních kostí, levé kosti patní a pravděpodobně levé kosti lod'kovité.

Po dokončení konzervace kovových artefaktů byly k dispozici další části skeletu, vyzvednuté s nimi původně in situ. Kromě drobných neidentifikovatelných fragmentů lze rozlišit malý zlomek přední plochy kosti křížové a větší část $\mathrm{z}$ levé kosti pánevní zahrnující oblast acetabula s přilehlou inc. ischiadica major - zlomek je velikostně i morfologicky v podstatě shodný s druhostranným, poněkud zřetelnější je malé acetabulum s ostrým okrajem.

Dle nemnoha hodnotitelných morfologických znaků i gracilní stavby náleží skelet pravděpodobně ženě, dle stupně obrusu chrupu zemřelé pravděpodobně v rozmezí věkových kategorií adultus I a II, konkrétně snad kolem 30. roku života. Výšku postavy nelze přesněji vypočítat. Žena byla křehké tělesné konstituce. Trpěla kazivostí chrupu a podle př́tomnosti výrazných cribra orbitalia patrně nespecifickou poruchou výživy v dětství (avitaminózy, hladovění, infekční choroby apod.; Horáčková et al. 2004).

\section{Závěr}

I přes nepříznivé okolnosti se na malé části stavby podařilo provést standardní záchranný archeologický výzkum, při němž bylo mimo jiné prozkoumáno 24 kostrových a 6 žárových hrobů z doby laténské. Větší část plochy a pravděpodobně také část pohřebiště zůstala bohužel neprozkoumána pro naprostou neochotu investora stavby najít kompromisní řešení.

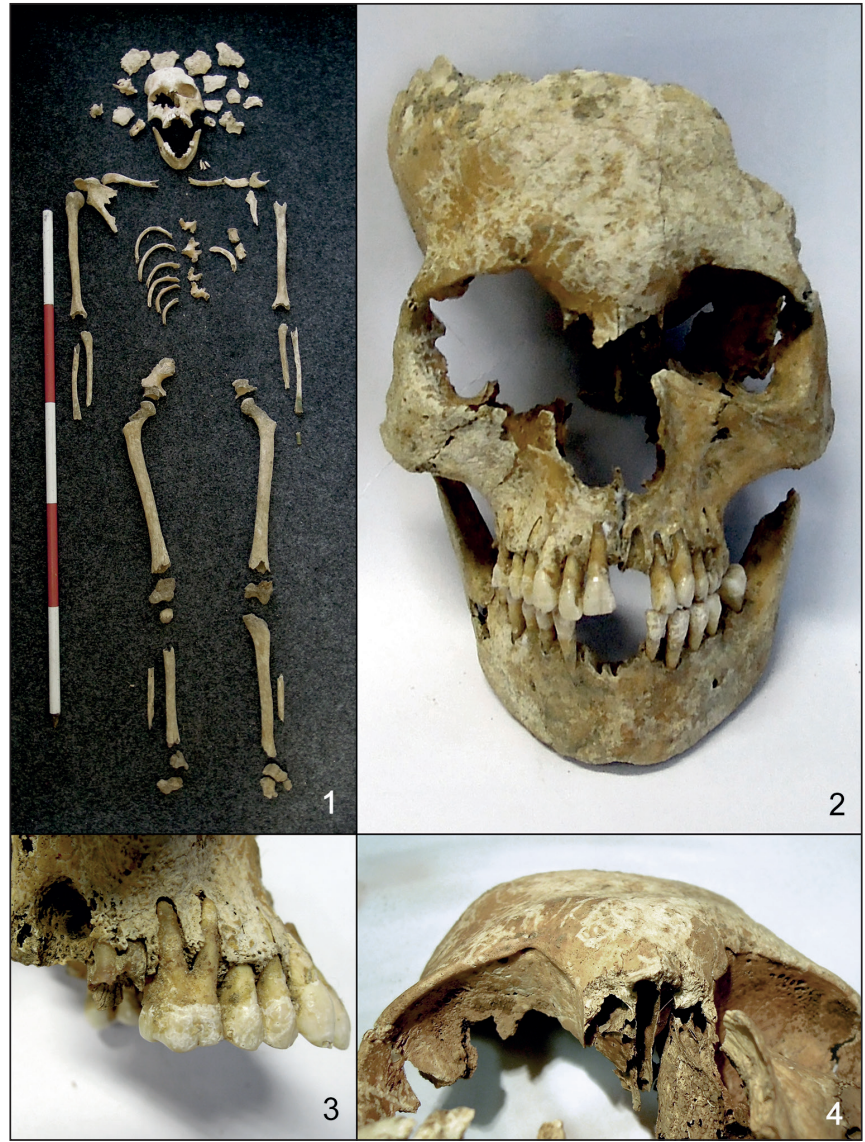

Obr. 13. Kosterní pozůstatky z hrobu H823; 1 - celkový pohled; 2 - obličejová část skeletu H823; 3 - detail pravé části horní čelisti (patrná je kazem zničená korunka druhé stoličky a polokulovité zánětlivé ložisko v místě alveolu stoličky třetí); 4 - nevýrazná cribra orbitalia ve stropech obou očnic. Foto J. Kala.

Fig. 13. Skeletal remains from grave H823; 1 - overall view; 2 - facial part of the skeleton H823; 3 - detail of the right part of the upper jaw (a caries-destroyed crown of the second molar and a hemispherical inflammatory nidus at the alveolus of the third molar are evident); 4 - bland cribra orbitalia in the ceilings of both eye sockets. Photo by J. Kala.

Jámy kostrových hrobů měly s drobnými odchylkami shodnou orientaci S-J, jejich uspořádání však nevykazovalo náznaky pravidelnosti (např. do řad). Hloubka hrobových jam byla velice různorodá; některé byly jen mělce zahloubené do podorničí, většina bohatě vybavených hrobů ovšem dosahovala hloubky až $120 \mathrm{~cm}$ od úrovně podloží.

Dvě svérázně provedené spony s velkou kuličkou na patce připojenou k lučíku datují bohatý hrob H823 na přelom stupňů LT B2 a LT C1. Další nálezy (bronzový náramek, opasek a méně často i švartnový náramek) se vyskytují také ve stupni LT C1 a chronologickému zařazení hrobu tak neodporují. Uvedené datování koreluje také s výsledky analýzy prvkového složení bronzových artefaktů, kterou bylo identifikováno specifické legování mědi značným množstvím olova.

Žárový hrob H821 již svým charakterem pohřebního ritu naznačuje mladší datování. Do stupně LT C1 je možné klást nález listu kopí se zachovaným rytým dekorem na tuleji. Datování podporuje také větší délka meče nebo výzdoba na torzu nádoby.

Aktuálně nebylo možno vyhodnotit všechny odkryté hroby z mladší doby železné nalezené na pohřebišti (nepochybně podstatně rozsáhlejším - blíže neurčený počet hrobů byl zavezen a zničen), a nelze tedy říci, zda jsou všechny současné s výše prezentovanými bohatými a dobře datovatelnými celky, či zda jsou mezi nimi i hroby starší a pohřebiště tak mělo větší časový rozsah. Určitý vývoj snad naznačuje horizontální stratigrafie pohřebiště, 
kdy kostrové hroby jsou jasně situovány ve východní části nekropole, zatímco žárové v západní. Časovou posloupnost pohřebního ritu potvrzuje také poloha výše vyhodnocených hrobů.

Z žárového hrobu bohužel s ohledem na mizivý antropologický materiál nedisponujeme žádnými informacemi o věku, pohlaví či př́íčině smrti zemřelého. Dle inventáře můžeme s jistotou tvrdit, že se jednalo o jedince s bojovnickým statusem, jehož mimořádné postavení může naznačovat neobvyklá součást výzbroje $\mathrm{v}$ podobě zdobeného listu kopí.

Kostrový hrob poskytuje více informací; jednalo se o gracilní ženu ve věku cca 30 let, u které byla prokázána porucha výživy v dětství. Byla útlejší postavy, čemuž nasvědčuje i na základě vyzvednutého opasku rekonstruovaný obvod pasu, který činil přibližně $60 \mathrm{~cm}$. Z oděvu zemřelé se na vnitřní straně břišní části opasku zachovaly pozůstatky textilií zachycené při konzervátorském zásahu. O tom, že žena patřila k vyšší společenské vrstvě v dané komunitě, dostatečně vypovídá její bohatá výbava. O př́ičině smrti je možné bohužel pouze spekulovat; pochovaná žena mohla zemřít při porodu, vyloučeno není také zranění, které není při antropologickém zhodnocení zjistitelné. Vedle bohatého inventáře je hrob mimořádný především silně torzovitě zachovalým pohřbem kojence bez milodarů, který byl uložen do zásypu hrobové jámy zemřelé. Varianta, že by šlo o značně mladší pohřeb je nepravděpodobná, ostatní hroby na nekropoli se jinak vzájemně respektují, navíc můžeme předpokládat, že hrob takto bohatě vybavené zemřelé byl také po dlouhou dobu náležitě označen. Je tedy spíše pravděpodobné, že byl pohřeb v tomto místě uložen úmyslně, v krátké časové následnosti, a souvisí s př́ibuzenskou vazbou na zemřelou.

Oba prezentované celky přinesly řadu nových zajímavých faktů a zjištění. Lze jen litovat, že v důsledku neochoty investora nebylo možno prozkoumat celou nekropoli, která mohla poskytnout množství nových informací důležitých pro poznání doby laténské v regionu (nejen) stř̌ední Moravy.

\section{Poděkování}

Studie vznikla s institucionální podporou na dlouhodobý koncepční rozvoj výzkumné organizace RVO: 68081758 - Archeologický ústav AV ČR, Brno, v. v. i.

\section{Poznámky}

1. Déle než měsíc trvalo další jednání mezi Ústavem archeologické památkové péče Brno, v. v. i. Národním památkovým ústavem, územním odborným pracovištěm v Brně, Archeologickým ústavem AV ČR, Brno, v. v. i. a firmou Ferobet. Majitel společnosti neústupně trval na tom, že archeologický výzkum není nutný, nebot skrývkou odkrytým hrobům nehrozí zničení, protože jsou ukryté v zemi. Během těchto jednání došlo dvakrát k pokusu o dokončení výzkumu, pracovníci Ústavu archeologické památkové péče Brno, v. v. i. však byli vždy ze stavby vykázáni.

2. Přicházející podzimní deště zapříčinily, že z mělce uložených hrobových jam byly vyplavovány kosterní pozůstatky, na jejichž přítomnost si stěžovali kolemjdoucí místní občané. Průzkum dalších sídlištních objektů (především keramické pece), jakož i větší části plochy, která zůstávala skryta pouze na úroveň podorničí, však ze strany investora umožněn nebyl. Naopak, v jarních měsících roku 2018 celou plochu zhutnil a zavezl recyklátem, čímž došlo ke zničení četných archeologických nálezů a situací.

3. Nálezy z pohřebiště jsou uloženy ve sbírkách Muzea Vyškovska ve Vyškově.

4. Ačkoliv průměr nelze rekonstruovat, byl přibližně odvozen od průměru sapropelitového nápažníku, který se nacházel na stejné končetině v bezprostřední blízkosti náramku.
5. Dle terénní dokumentace ležela prohnutá část nápažníku př́mo pod kostí horní končetiny, je tedy možné, že byl předmět deformován právě tímto způsobem.

6. Vybrané komplexnější kovové nálezy byly ošetřeny v konzervátorské laboratoři Archeologického ústavu AV ČR, Brno, v. v. i. v Mikulčicích. Přesněji jde o železný meč s pochvou a kopí z hrobu H821, jejž konzervoval Michal Chovanec, DiS., a bimetalický opaskový řetěz z hrobu H823, který konzervoval Mgr. Matěj Kmošek, DiS. Ostatní drobnější kovové nálezy byly ošetř̌eny separátně v konzervátorské laboratoři Ústavu archeologické památkové péče Brno, v. v. i.

7. Prvkové analýzy byly provedeny u dvojice spon A 119896 a A 119897, náramku A 119898 a čtyř článků opaskového řetězu A 120023.

\section{Literatura}

Benadik, B. 1957: Archeologický materiál a jeho hodnotenie. In: B. Benadik, E. Vlček, C. Ambros (eds.): Keltské pohrebiská na juhozápadnom Slovensku. Bratislava: Vydavatel'stvo Slovenskej akadémie vied, 1-200.

Benadik, B. 1960: Keltské pohrebisko v Bajči-Vlkanove. Slovenská archeológia VIII(2), 393-456.

Benadik, B. 1983: Man̆a. Keltisches Gräberfeld. Fundkatalog. Nitra: Archäologisches Institut der Slowakischen Akademie der Wissenschaften.

Benešová, J. et al. 2011: Konzervování a restaurování kovů. Ochrana předmětů kulturního dědictví z kovi̊ a jejich slitin. Brno: Technické muzeum v Brně, Metodické centrum konzervace.

Brunaux, J. L., Lambot, B. 1987: Guerre et armement chez les Gaulois (450-52 av. J.-C.). Paris: Errance.

Bujna, J. 1995: Malé Kosihy. Latènezeitliches Gräberfeld. Katalog. Nitra: Archeologický ústav Slovenskej akadémie vied v Nitre.

Bujna, J. 2003: Spony z keltských hrobov bez výzbroje z územia Slovenska. Typovo-chronologické triedenie LT B- a C1 spôn. Slovenská archeológia LI(1), 39-108.

Bujna, J. 2005: Kruhový šperk z laténskych ženských hrobov na Slovensku. Nitra: Filozofická fakulta UKF Nitra, Archeologický ústav SAV Nitra.

Bujna, J. 2011: Opasky ženského odevu z doby laténskej. Nitra: Univerzita Konštantína Filozofa v Nitre, Filozofická fakulta.

Červinka, I. L. 1902: Morava za pravěku. In: I. L. Červinka (ed.): Vlastivěda moravská I. Země a lid. Brno: Musejní spolek.

Čižmář, I., Kala, J. 2015: Rajhrad. Laténský žárový hrob z Rajhradu (okr. Brno-venkov). Pravěk Nová řada 24, 201-212.

Čižmář, I., Lečbych, M. 2013: Doba laténská. In: K. Geislerová, D. Parma (eds.): Výzkumy - Ausgrabungen 2005-2010. Brno: Ústav archeologické památkové péče Brno, 98-114.

Čižmář, M. 1984: Laténské sídliště z Velkých Hostěrádek. Památky archeologické LXXV(2), 463-485.

Čižmář, M. 1991: Neue Erkenntnisse zur Verzierung keltischer Waffen in Mähren. Études celtiques XXVIII, 127-136.

Čižmář, M., Geisler, M. 1987: Rettungsgrabungen auf dem Bau der Autobahn im Abschnitt Holubice - Tučapy im Jahre 1985 (Bez. Vyškov). Přrehled výzkumů 1985, 65-66, obr. 21-22.

Čižmářová, J. 2005: Keltské pohřebiště v Brně-Maloměřicích. Pravěk, Supplementum 14. Brno: Ústav archeologické památkové péče Brno.

Čižmářová, J. 2009: Keltská pohřebiště z Holubic a Křrenovic. Pravěk, Supplementum 19. Brno: Ústav archeologické památkové péče Brno, v. v. i.

Čižmářová, J. 2011: Keltská pohřebiště na Moravě. Okresy Brno-město a Brno-venkov. Brno: Moravské zemské muzeum.

Čižmářová, J. 2013: Keltská pohřebiště na Moravě. Okresy Blansko a Vyškov. Brno: Moravské zemské muzeum. 
Čižmářová, J. 2017: Keltská pohřebiště na Moravě. Okresy Hodonín, Kroměř̌̌, Olomouc, Opava, Prostějov, Přrerov, Uherské Hradiště a Zlín. Brno: Moravské zemské muzeum.

Dokládal, M. 1999: Morfologie spálených kostí. Sborník prací lékařské fakulty 113. Brno: Lékařská fakulta Masarykovy univerzity.

Filip, J. 1956: Keltové ve střední Evropě. Praha: Nakladatelství Československé akademie věd.

Frána, J., Jiráň, L., Moucha, V., Sankot, P. 1997: Artifacts of copper and copper alloys in prehistoric Bohemia from the viewpoint of analyses of element composition II. Památky archeologické, Supplementum 8. Praha: Archeologický ústav AV ČR, Praha.

Furman, M. 2014: Variabilita keltských kruhových garnitúr v stredoeurópskom priestore so zretel'om na použité suroviny. In: J. Čižmářová, N. Venclová, G. Březinová (eds.): Moravské kř́ižovatky. Střední Podunají mezi pravěkem a historí. Brno: Moravské zemské muzeum, 493-514.

Geislerová, K., Parma, D. 2013: Výzkumy - Ausgrabungen 2005-2010. Brno: Ústav archeologické památkové péče Brno, v. v. i.

Geislerová, K., Parma, D. 2018: Výzkumy - Ausgrabungen 2011-2016. Brno: Ústav archeologické památkové péče Brno, v. v. i.

Guštin, M. 1984: Die Kelten in Jugoslawien. Übersicht über das archäologische Fundgut. Jahrbuch des Römisch-Germanischen Zentralmuseums 31, 305-363.

Horáčková, L., Strouhal, E., Vargová, L. 2004: Základy paleopatologie. Brno: Masarykova univerzita.

Horák, J. 2012: Zdobené pochvy laténských mečů z Moravy. Pravěk Nová řada 20, 260-261.

Chakrabarti, D. J., Laughlin, D. E. 1984: The $\mathrm{Cu}-\mathrm{Pb}$ (Copper-Lead) system. Bulletin of Alloy Phase Diagrams 5, 503-510.

Kmošek, M. 2019: Měd’ a její slitiny jako surovina kovové industrie v pravěku a protohistorii na území jižní Moravy [online]. Rkp. diplomové práce. Masarykova univerzita. Filozofická fakulta. Ústav archeologie a muzeologie. Uloženo: Archiv závěrečných prací Masarykovy univerzity [cit. 2020-05-18]. Dostupné z: https://is.muni.cz/th/ml8ni/.

Knussmann, R. 1988: Anthropologie. Handbuch der vergleichenden Biologie des Menschen. Band I: Wesen und Methoden der Anthropologie. Jena: Gustav Fischer Verlag.

Ličman, A. 1921: Slavkovský okres. Vlastivěda moravská. II. Místopis Moravy. Brněnský kraj. Brno: Musejní spolek.

Lovejoy, C. O. 1985: Dental Wear in the Libben Population: Its Pattern and Role in the Determination of Adult Skeletal Age at Death. American Journal of Physical Anthropology 68(1), 47-56.

Meduna, J. 1980: Die latènezeitliche Siedlungen in Mähren. Praha: Academia, nakladatelství Československé akademia věd.

Meduna, J., Peškař, I. 1992: Ein latènezeitlicher Fund mit Bronzebeschlägen von Brno-Maloměřice (Kr. Brno-Stadt). Bericht der Römisch-Germanischen Kommission 73, 182-267.

Megaw, J. V. S., Megaw, M. R. 2009: Hare or Hind? The decorated spear from Kandija grave K44. In: G. Tiefengraber, B. Kavur, A. Gaspari (eds.): Keltske studije II. Studies in Celtic Archaeology. Papers in honour of Mitja Gustin. Montagnac: Editions Monique Mergoil, 163-172.

Mikulková, B. 2018a: Doba římská a doba stěhování národů. In: K. Geislerová, D. Parma a kol.: Výzkumy - Ausgrabungen 2011-2016. Brno: Ústav archeologické památkové péče Brno, 100-115.

Mikulková, B. 2018b: Rousínov (k. ú. Rousínov u Vyškova). Přehled výzkumů 59(1), 136, 198, 212.

Nerantzis, N. 2015: Experimental simulation study of prehistoric bronze working: testing the effects of work-hardening on replicated alloys. In: A. Hauptmann, D. Modaressi-Tehrani (eds.): Archaeometallurgy in Europe III. Der Anschnitt, Beiheft 26. Bochum: Deutsches Bergbau-Museum, 329-335.
Peška, J., Králík, M., Selucká, A. 2006: Rezidua a otisky organických látek v korozních produktech mědi a jejích slitin. Pilotní studie. Industrie starší doby bronzové. Památky archeologické XCVII, 5-46.

Pittioni, R. 1930: La Tène in Niederösterreich. Vienna: Private Press of the Anthropologische Gesellschaft.

Pleiner, R. 1993: The Celtic Sword. Oxford: The Clarendon Press.

Pollard, A. M., Bray, P. 2014: Chemical and Isotopic Studies of Ancient Metals. In: B. W. Roberts, C. P. Thornton (eds.): Archaeometallurgy in Global Perspective. Methods and Syntheses. New York: Springer, 217-238.

Procházka, A. 1937: Gallská kultura na Vyškovsku. La Tène středomoravský. 1. Část archeologická. Slavkov u Brna: vlastním nákladem.

Přichystal, M. 2005: Rousinov 2005 „U Kmentovy cihelny“. Rkp. nálezové zprávy č. j. 113/05. Uloženo: Archiv Ústavu archeologické památkové péče Brno, v. v. i.

Ramsl, P. C. 2006: Die durchbrochen gearbeitete Lanzespitze aus Grab 180 von Mannersdorf/Lgb., Flur Reintal Süd (Archäologischkunsthistorische Analyse). Pravěk Nová řada 16/2006, 185-200.

Rosen-Przeworska, J. 1963: Fin de l'Age du Bronze - Age du Fer. Inventaria Archaeologica. Pologne IX. Pl 47-Pl 54. Łódź, Warszawa: Państwowe wydawnictvo naukowe.

Stloukal, M., Hanáková, H. 1978: Die Länge der Längsknochen altslawischer Bevölkerungen unter besonderer Berücksichtigung von Wachstumsfragen. Homo 29(1), 53-69.

Szabó, M., Petres, E. F. 1992: Decorated weapons of the la Téne iron age in carpathian basin. Inventaria praehistorica Hungariae V. Budapest: Magyar Nemzeti Múzeum.

Teleagă, E. 2008: Die La-Tène-zeitliche Nekropole von Curtuiuşeni/ Érkörtvélyes (Bihor, Rumänien). Der Forschungsstand. Dacia 52, 85-165.

Venclová, N. 1995: Specializovaná výroba: Teorie a modely. Archeologické rozhledy XLVII(4), 544-564.

Venclová, N. 2001: Výroba a sídla v době laténské. Praha: Archeologický ústav Praha.

Vlček, E. 1994: Metodika určování zubního věku podle stupně mineralizace chrupu v historické antropologii a paleoantropologii. Stomatologické zprávy 35(3), 30-39.

Waldhauser, J. (ed.) 1978: Das keltische Gräberfeld bei Jenišưv Újezd in Böhmen. II. Band Auswertung. Archeologický výzkum v severních Čechách 6-7. Teplice: Krajské muzeum Teplice.

Waldhauser, J. 1987: Keltische Gräberfelder in Böhmen. Bericht der Römisch-Germanischen Kommission 68, 25-179.

\section{Summary}

In 2017, the Institute for Archaeological Heritage Brno carried out a development-led excavation on the construction site of the warehouse area and utility road in the Ferobet company premises in Rousínov (Fig. 1, 2). During the excavation, a greater part of a La Tène period cemetery was uncovered among other features. Due to the investor's uncooperative attitude it was not possible to properly investigate the area of the La Tène cemetery in its entirety. Despite the unfavorable conditions, it was possible to uncover 30 La Tène period graves (24 inhumations and 6 cremations). The grave pits of the inhumations were all oriented in roughly N-S direction with slight variation, but their arrangement did not show any signs of regularity (e.g. into rows). The cremation graves were partially concentrated in the western part of the cemetery. Two graves differed significantly from the majority of the less prominent burials and deserve a detailed study of their intriguing furnishings. These were the warrior's cremation grave H821 (Fig. 3, 4) and the rich female inuhmation H823 (Fig. 3, 6). 
The grave H821 (feature 553) was a cremation with a very shallow pit that was sunken only $5 \mathrm{~cm}$ below the surface level. The grave pit measuring $187 \times 98 \times 7 \mathrm{~cm}$ was oriented in the W-E direction and was of rectangular shape with rounded corners and a shallow bowl profile (Fig. 3: 1; Fig. 4; Fig. 5). In the central part of the grave an undeformed iron sword was placed diagonally. Its blade has a faint central rib and the hilt was broken; hilt rivets were found as well (2). The heavily damaged scabbard featured a suspension loop with round attachment plates and two trough-shaped chape fragments (3). Underneath the sword there was part of iron chain-belt with oval links and terminating in two circular loops (4a, $4 b)$, as well as a fragment of an iron bracelet (5). A spear-head was found at the northern edge of the grave pit. Its socket is decorated with engraved decoration of S-shaped and fish bladder motifs inscribed in circles (1). Fragments of a secondarily burnt ceramic vessels were located nearby (7-11). Other fragments (6) of a burnt ceramic vessel decorated with stamping lay near the sword (Fig. 3: 2). The skeletal remains of the cremation were scattered all over the grave pit. It was not possible to anthropologically determine the throughly cremated skeletal remains, but they probably belonged to an adult. A higher concentration of burnt skeletal fragments was found under the accumulation of ceramics (6). On the basis of the grave inventory, especially the spear-head with its decorated socket, the grave can be dated to LT C1.

The grave H823 (feature 528) is an inhumation with a grave pit oriented in the N-S direction. The grave pit intersected a prehistoric settlement feature. The pit measuring $270 \times 120 \times 45 \mathrm{~cm}$ was rectangular in shape with rounded corners. At the bottom there was a small rectangular depression $(158 \times 71 \times 17 \mathrm{~cm})$, which probably originated from wooden lining or coffin. In the depression lay a skeleton placed in a prone outstretched position with head to the north, arms along the body and face turned to the right (Fig. 3: 3; Fig. 6; Fig. 7). On the shoulders there were two identical bronze fibulae with a large knob on the foot attached to the bow with a decorated clamp ( 1 - right shoulder, 2 - left shoulder), another iron fibula was on the right side of the chest (3). A sapropelite (4) and an iron (5) armring were worn in the elbow area of the left arm. On the wrist of same arm, there was a bronze bracelet (8), made of a thin rod, on which cast cuboids decorated with concentric rings were strung. Bronze (9) and iron (14) rings were worn on the fingers of the left hand. Fragments of an iron wire spiral bracelet were located at the right wrist (7). Between the right femur and the wall of the grave pit there were two ceramic vessels $(10,11)$ and a fragment of another vessel (13). In the waist area, a complete bimetallic chain-belt (6) was found, consisting of larger bronze rings joined by two chains of smaller iron links with locally preserved textile remains (Fig. 12: 3, 4). The horizontal part of the belt was placed around the perimeter of the abdomen above the waist level (waist circumference approx. $60 \mathrm{~cm}$ ) and its vertical part was directed over the left pelvic bone to the left femur (Fig. 3: 3). The exceptional character of this grave is also enhanced by the remains of a newborn child, buried without furnishing (H822) in the grave backfill. Analysis of the elemental composition of copper alloy artefacts from grave $\mathrm{H} 823$ showed a high proportion of lead in the alloy (Tab. 1, 2), a phenomenon characteristic since La Tène B2 period. Using anthropological analysis, it was determined that the skeleton probably belonged to a woman of gracile body constitution, who died around the age of 30 . The woman suffered from dental caries and probably a non-specific nutritional disorder in childhood. The grave goods of the inhumation can be dated to the LT B2/C1.

Translation J. Kysela

\section{Kontakty:}

Ivan Čižmář

Ústav archeologické památkové péče Brno, v. v. i.

Kaloudova 1321/30

CZ-614 00 Brno

ivancizmar@uapp.cz

\section{Blanka Mikulková}

Ústav archeologické památkové péče Brno, v. v. i.

Čsl. armády $1 / 2 \mathrm{~A}$

CZ-682 00 Vyškov

mikulkova@uapp.cz

Matěj Kmošek

Archeologický ústav AV ČR, Brno, v. v. i.

Čechyňská 363

CZ-602 00 Brno

kmosek@arub.cz

\section{Michal Chovanec}

Archeologický ústav AV ČR, Brno, v. v. i.

Mikulčice 736

CZ-696 19 Mikulčice

chovanec@arub.cz

\section{Jiří Kala}

Ústav archeologické památkové péče Brno, v. v. i. Kaloudova 1321/30

CZ-614 00 Brno

kala@uapp.cz 
